Ministerstwo Nauki

i Szkolnictwa Wyższego

Digitalizacja archiwalnych numerów czasopisma naukowego Analecta Cracoviensia 1-24 (1969-1992)

i ich publikacja w otwartym dostępie - zadanie finansowane w ramach umowy 672/P-DUN/2017 ze środków

Ministra Nauki i Szkolnictwa Wyższego przeznaczonych na działalność upowszechniającą naukę

\title{
H. RENGSTORFA KONCEPCJA APOSTOLATU NOWOTESTAMEN'TALNEGO I JEJ REPERKUSJE W EGZEGETYCZNO-TEOLOGICZNEJ LITERATURZE PROTESTANCKIEJ PRZED II SOBOREM WATYKAŃSKIM
}

W toczącej się już przeszło od półtora wieku dyskusji nad zagadnieniem apostolatu nowotestamentalnego szczególne miejsce zajmuje koncepcja reprezentanta wyznania luterańskiego w Szweəji, H. Rengstorfa ${ }^{1}$, jednego z najwybitniejszych znawców tego zagadnienia. Przedsitawieniu jej, wraz z próbą oceny krytycznej oraz ze wskazaniem na oddźwięk, jaki znalazıa ona we współczesnej protestanckiej literaturze egzegetyazno-teologicznej, służy niniejszy artykuł.

\section{GENEZA I ZNACZENIE TERMINU APOSTOLOS}

W dociekaniach Rengstorfa poświęconych zagadnieniu apostolatu nowotestamentalnego można wyróżnić dwa główne, ściśle ze sobą związane tematy, na których koncentruje cn swoją uwagę. Są nimi zagadnienia genezy i istoty tegoż apositolatu. Dla wyjaśnienia genezy apostolatu podejmuje Rengstorf najpierw wnikliwe dociekania nad znaczeniem czasownika apostello i rzeczownika apostolos w literaturze greckiej oraz odpowiadających im form czasownikowych i rzeczownikowych w hebrajskim tekście Starego Testamentu, następnie dociekania nad żydowską instytucją šaliach, wreszcie nad zastosowaniem wymienionych terminów w Nowym Testamencie. Oto najważniejsze rezultaty tych dociekań.

Czasownik apostellein z podstawowym znaczeniem ,,wysyłać”, ,posyłać", obok prostego stellein, stanowi - jak wykazuje Rengstorf - stały sklađinik literatury greckiej i języka potocznego zarówno w czasach kla-

1 Zob. H. Rengstorf, apostello, w: I (ThWNT) 397-406; apostolos, tamże, I, 406 446; dôdeka, tamże, II, 321-328; Apostolat und Predigtamt, Stuttgart 1934; drugie niezmienione wydanie: Stuttgart 1954; Die Zuwahl des Matthias, „Studia Theologica", cura ordinum theologicorum Scandinavicorum edita, Lund, 15 (1961) 35-67. 
sycznych jak i w helleniźmie i bywa często używany na oznaczenie wysłania osób i rzeczy. Apostellein jako wyraz złożony ze stellein stanowi w stosunku do tego czasownika pewne wzmocnienie. Daje się to zauważyć szczególnie w tych przypadkach, w których apostellein używane jest w sensie przenośnym lub jako termin techniczny. W tych razach mocny akcent położony jest na świadomość celu i dążenie do niego. Apostellein różni się również od pempein. Podezas gdy w przypadku użycia pempein chodzi przede wszystkim o posłanie jako takie, o fakt posłania, to apostellein wyraża, że posłanie dokonuje się pod określonym, jedynym w swoim rodzaju kątem widzenia, który odnosi się nie tylko do posyłającego i odbioncy, lecz także do posłanego, względnie do rzeczy stanowiącej przedmiot wysłany. Zgodnie z tym z apostellein związany jest ten sens uboczny, że posłanie oznacza zarazem mandat przywiązany do osoby posłanego ${ }^{2}$.

Jako przykład ilustrujący bliżej zastosowanie apostellein w podanym znaczeniu wymienia Rengstorf formułe apestalmenoi hypo tou basileōs. Formuła ta łączy mianowicie $z$ ideą posłania dalszą ideę autoryzacji posłaniego. Mężowie, o których w tym przypadku jest mowa, są wręcz przedstawicielami swego monarchy i wyrazicielami jego autorytetu. Za-stosowanie słowa apostellein $\mathrm{w}$ tym znaczeniu nie ogranicza się jednak bynajmniej do sfery prawnej. Jego punkt kulminacyjny występuje diopiero tam, gdzie staje się ono wyrażeniem służącym na oznaczenie udzielenia plenipiotencji religijno-moralnej. Miało to miejsce $\mathrm{w}$ diatrybie cynicko-stoickiej, która przejęła wszakże jedynie słownictwo religijno-filozoficzne. Tak więc u Epikteta apostellein jest terminem technicznym na oznaczenie upełnomocnienia przez bóstwo, natomiast pempein jest używane tam, gdzie chodzi o upełnomocnienie cynika do określonego zadania w oparciu o inicjatywę ludzi. W podobnym znaczeniu jak Epiktet używa zresztą słowa apostellein Ireneusz i Filon z Aleksandrii. Fakt ten, tzn. użycie wymienionego słowa przez mężów, którzy należeli do różnych kręgów kulturowych i zamieszkiwali różne krainy, nie jest bez znaczenia dla ukształtowania terminu służącego chrześcijanom do wyrażenia idei posłannictwa. Pierwotne znaczenie słowa apostellein nie zacieśniło się jednak do wyłącznego znaczenia boskiego posłanniatwa i upoważnienia człorwieka. Jest to raczej tylko punkt kulminacyjny w rozwoju tego wyrażenia. Obok tego znaczenia wymienionego czasownika utrzymywało się nadal, aż do prachrześcijańskich czasów, jego pierwotne, zupelnie świeckie znaczenie ${ }^{3}$.

W Septuagincie apostellein występuje przeszło 700 razy, prawie wyłącznie dla oddania hebrajskiego czasownika šalach = posyłać, rożsyłać.

$2 \mathrm{I}(\mathrm{ThWNT}) 397$.

3 Tamże, $397 \mathrm{nn}$. 
Apostellein używane jest tu również w przypadkach, w których chodzi o powierzenie posłannictwa lub zadania. Nadto słowio to jest terminem technicznym na oznaczenie posłania wysłannika ze specjalnym mandatem, przy czym sam ów wysłannik nie musiał być wymieniony. Przy takim użyciu akcent położony jest na fakcie posłania $\mathrm{w}$ łączności $\mathrm{z}$ osobą wysyłającego, natomiast osoba wysłanego schodzi na plan dalszy ${ }^{4}$. Godnym uwagi - jak podkreśla Rengstorf - jest tutaj fakt, że słowo apostellein w Septuagincie, podobnie jak šalach w hebrajskim tekście Starego Testamentu, nie ma religijnego zabarwienila. Nawet $w$ opisach posłania proroków nie mamy do czynienia ze słownictwem religijnym. W tym zastiosowaniu wymienione słowo używane jest po prostu na oznaczenie posłania, a religijny wydźwięk otrzymuje tylzo ze względu na religijne uwarunkowanie sytuacji ${ }^{5}$.

W judaizmie rabinistycznym użycie słowa šalach pozostaje całkłowicie w nakreślonych wyżej ramach. Nigdzie nie dostrzega się przekroczenia jego świeckiego sensu. Spośród pisarzy żydowskich posługujących się językiem greckim Józef Flawiusz używa często słowa apostellein bądź to synonimicznie $z$ pempein, bądź też w szczególnym sensie na oznaczenie oficjalnego posłania jako takiego. Jedynie Filon, podobnie jak diatryba cynicko-stoicka, zna użycie czasownika apostellein $\mathrm{w}$ sensie religijnym. Przez to stoi on w odoscibnieniu zarówno w stosunku do rabinatu, jak i. Józefa Flawiusza ${ }^{6}$.

W Nowym Testamencie apostellein użyte jest 135 razy; często także - bo w osiemdziesięciu przypadkach - występuje pempein. Między znaczeniami tych słów występuje tu pewna różnica. Przy użyciu pempein akcent spoczywa na mandacie związanym z posłaniem, niezależnie od tego, czy na plan pierwszy akcji wysuwa się wysyłający czy posłany. Charlakterystyczną rzeczą jest przy tym, że synoptycy nie stosują nigdy słowa tego w odniesieniu do Boga, leoz posługują się w tym celu czasiownikiem apostellein. Po thej linii idzie także Paweł. Natomiast Ewangelia Jana używa, jak się zdaje, apostellein zamiennie z pempein. Na słowach tych swoiste piętno wycisnęła Janowa chrystologia. Wszakże nie stały się one $\mathrm{u}$ Jana terminami teologicznymi, lecz jedynie zostały wzięte $\mathrm{z}$ języka świeckiego i wypełnione religijną treścią. Ujmując rzecz sumarycznie można powiedzieć, że w Nowym Testamencie słowo apostellō zaczyna stawać się terminem technicznym (por. Mt 10, 5, 16; Łk 22, 35; Rz 10, 15; Kor 1, 17) i otrzymuje sens: wysyłać z plenipotencją (mającą podsitawę w Bogu) do służby w Królestwie Bożym. Nie mamy tu jednak do czynienia $z$ rozwojem sensu mającym swe źródło we właściwym znacze-

4 Tamże, 399.

5 Tamże, 401.

6 Tamże, 401 n. 
niu tego słowa. Jego sens uzależniony jest raczej wyraźnie od znaczenia rzeczownika apostolos ${ }^{\top}$.

Rzeczownik apostolos — jak wywodzi dalej Rengstorf - znany był już starożytnym Grekom. Mistrzowie szkoły attyckiej, Lizajasz i Demostenes, używali tego rzeczownika jako wzmonnienia od stolos na oznaczenie floty czy ekspedycji morskiej. Platon rozumiał przez to apostolon ploion statek transportowy; u Dionizego z Halikarnos oznaczał apostolos grupę osadnilków. W papirusach oznaczał ten wyraz list przewozowy albo perwien rodzaj paszportu. Przykłady te świadozą, zdaniem Rengstorfa, że w klasyaznej greczyźnie dominuje znaczenie bienne wyrazu apostolos w sensile czysto zewnętrznego posłania. Znaczeniu temu brak jest cechy upełnomocnienia i osobistego przedstawicielsitwa, dlatego też wyraz apostolos nie był zwyczajnie używany na oznaczenie posłańca w technicznym znaczenciu tego słowa. Do tego celu używane były raczej inne sława, m. in. angelos, kèryks, presbytes. Dlatego też późniejsze użycie słowa apostolos przez chrześcijian było odczuwane przez Greków jako coś zupełnie nowego, w konsekwencji czego łacinnicy nie przetłumaczyli go, lecz przejęli do łacińskiego języka kościelnego jako obce słowo apostolus. Tlakże i w dwóch przypadkach, w których słowo apostolos występuje lub zdaje się występować w literaturze jońskiej, mianowicie u Herodota, uwidacznia się cecha posłannictwa, względem której cecha upelnomocnienia usitępuje na plan dalszy ${ }^{8}$.

Stwierdziwszy, że stosunek greckiego apostolos do chrześcijańskiego apostolos ogrianicza się jedynie do formuły słowniej, stawia Rengstorf z kolei pytanie, jaki jest rzeczowy związek chrześcijańskiego apostolatu ze śwliatiem greckim. Zwliązek ten, zdaniem jego, jest bardzo znikomy, bowiem starożytne czasy nie znały niczego, co mogłoby stanowić paralelę $z$ apostolatem nowotesitamentalnym. Pewien wyjątek stanowili jedynie cyniiczno-stoiccy mędrcy, uważający się za wysłanników Zeusa i poczuwający się do odpowiedzialności wobec niego. Nie nazywali się jednak oni apostoloi lecz kataskopoi, nadito moment prawny nie odgrywal $\mathrm{u}$ mich istotnej roli 9 .

Pewne zbliżentie znaczenia słowa apostolos do jego znaczenia w Nowym Testamenaie występuje u Józefa Flawiusza i w Septuagincie. W Antiquitates Iudaicae pewme jest użycie go tylko w jednym miejseu, gdzile ozniacza on poiselstwo wysłane przez Żydów do Rzymian ${ }^{10}$. W Septuagincie rzeczownik apostolos, będący tłumaczeniem hebrajskiego imiesłowu biernego šaluach, utworzonego od czasownika šalach, użyty jest równileż tylko jeden raz, mianowiicie w $\mathrm{Krl} 14,6$, gdzie prorok Achiasz

7 Tamże, 402-405.

8 Tamże, $406 \mathrm{n}$.

9 Tamże, $408-412$.

10 Tamże, 413. 
powwiada do żony króla Jeroboama, przychodzącej dowiedzieć się o los jej chorego syna: egō eimi apostolos pros se sklèros, co w wolnym przekładzie znaczy: jestem upełnomocnionym (domyślnie: przez Boga) zwiastunem do oznajmienia ai twardego słowa. Podiobnie również i Akwila tłumarzy $\mathrm{w}$ cyttowanym miejscu šatuach przez apostolos. Wyraz ten oznacza tu posłańca Bożego w technicznym znaczeniu tego słowa, co wyraża się $w$ tym, że Achiaszowi zostaje udzielone pełnomocnictwo udania się ze słowem Bożym do żony króla. Znika tutaj świeckie znaczenie źródlowego czasownika šalach-apostellein na korzyść znaczenia religijnego, od kstórego otrzymuje swój sens wyraz apostolos ${ }^{11}$.

\section{INSTYTUCJA ŠALIACH}

Instytucją šaliach zajmowało się wielu badacszy przed Rengstorfem. Wypada tu zauważyć, że już anglikański uczony J. Lightfoot wyjaśniając znaczenie słowa apostolos wskkazał na różne znaczenia jego hebrajskliego odpowiednika šaliach ${ }^{12}$. Z kolei A. Harnack dopatrywał się zależności między instytucją šaliach a apostolatem chrześcijańskim, a nawet sądził, że wymientiona insitytucja sitanowiła dla niego pewien wzór ${ }^{13}$. Instytucja żydowskiego apostoła šaliach stała się następnie przedmiotem wnikliwych badań ze strony takich uczonych jak S. Krauss ${ }^{14}, \mathrm{H}$. Vogelstein ${ }^{15}$, P. Billerbeck ${ }^{16}$. Badiania te prowadził dalej i rozwijał H. Rengstorf.

Analizując odnośne teksty literatury żydowskiej starał się Rengstorf przede wszystkim określić istotną cechę tej instytucji. Zdaniem jego, cecha ta wyraża się w funkeji pełnomonnika. W rabinistycznym judaizmie z czasów Jezusa Chrystusa zname było - jak wywodzi Rengstorf - pochodzące $z$ semickiego prawa poselskiego pojęcie takiej funkcji. Wyraża ją przekazana przez Misznę maksyma: pełnomocnik — šaliach - jakiegoś człowieka znaczy (= ma wartość, może, jest w stanie spelnić) tyle, co sam ów człowiek. Wysłannik jest przeto zastępcą mocodawcy (por.

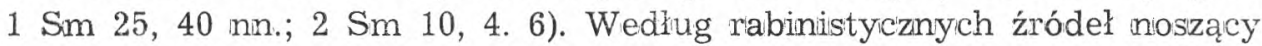
tytuł šaliach mógł np. prawnie dokonywać zaręczyn; poszczególni rabini występujący $w$ tej roli byli wysyłani na wizytację i na zebrania (także

11 Tamże.

12 J. Lightfoot, Saint Paul's Epistle to the Galatians. Exkurs: The Name and Office of an Apostle, London ${ }^{11}$ 1892, 93.

13 A. Harnack, Die Mission und Ausbreitung des Christentums in den ersten drei Jahrhunderten, Leipzig 1902, $237 \mathrm{nn}$.

14 S. Krauss, Die jüdischen Apostel, „The Jewish Quarterly Review", Philadelphia, 17 (1905) 370-382.

${ }_{15}$ H. Vogelstein, Die Entstehung und Entwicklung des Apostolats im Judentum, ,Monatsschrift für Geschichte und Wissenschaft des Judentums", Breslau, 49 (1905) $427 \mathrm{n}$.

16 P. Billerbeck - H. Strack, Kommentar zum Neuen Testament aus Talmud und Midrasch, III, München 1926, 2 nn. 
do diaspory) jako zastępcy sanhedrynu. Wysłanicy ai nie byli jednak misjonarzami i odwrotnie: żydowscy misjonarze z czasów Chrystusa nie nazywali się nigdy šeluchim. Ich działalność nie była poprzedzona upoważnieniem przez gminę i nosiła prywatny charakter. Judaizm nie znał zresztą wcale misji w sensie oficjalnego posłannictwa, a więc pojęcie šaliach nie mogło znaleźć zastosowania w odniesieniu do religijnej działalności misyjnej. Także i prorocy (mimo Iz 6,8) nie byli właściwie šeluchim; jedynie mężowie Boży, przez których dokonane zostały wielkie dzieła Boże, jak np. Mojżesz, Eliasz, Ezechiel i inni, nazwani byli šeluchim Boga. Wyraz šaliach nie oznacza tedy - jak konkluduje Rengstorf - jakiegoś trwałego unzędu. Oznacza natomiast wykonywanie funkcji, która przez określony mandat ograniczona jest rzeczowo i czasowo oraz kończy się wraz z jego wypełnieniem ${ }^{17}$.

\section{APOSTOLOS A $\check{S} A L I A C H$}

Porównując powyższe dane $\mathrm{z}$ wynikami prowadzonych $\mathrm{w}$ dalszym ciągu swej rozprawy badań nad zastosowaniem wyrazu apostolos w Nowym Testamencie, usiłuje Rengstorf bliżej określić relacje zachodzące między żydowskim šaliach a chrześaijańskim apostolatem. Jeśli chodzi o relację słowną, sprawa jest prosta. Nie ulega wątpliwości, że w myśl Rengstorfa relacja ta polega na pewnej zależności genetycznej, w tym znaczeniu, że šaliach zositał przetłumaczony na apostolos dzięki podobieństwu treści pojęć odpowiadających tym terminom ${ }^{18}$.

O tym, kiedy to nasitąpiło, nie da się, według Rengstorfa, nic pewnego powiedzieć. Pewnym, jak sądzi, jest chyba tylko to, że wybór wymienionego wyrazu nie został dokonany przez Żydów, bowiem gdyby rzeoz tak się miała, to porwinnyby istnieć liczniejsze świadectwa jego użycia. Być może, że przejęcie go nastąpiło w Antiochii syryjskiej, i to w ten sposób, że oznaczał on najpierw wyprawę misyjną, a następnie poszczególnych jej członków. Za taką możliwością przemawia, zdaniem Rengstorfa, to, że poza distami Pawłowymi wyraz ów występuje w Nowym Testamencie ciągle $w$ liczbie mnogiej. W końcu - jak konkluduje Rengstorf - wyraz apostolos okazal się terminem odpowiednim dla addania hebrajskiego šaliach, zwłaszcza że wyraz ten jest również rzeczownikiem rodzaju męskiego. Rengstorf nie wyklucza tutaj możliwości, że w utworzeniu wyrazu apostolos brał udział Paweł, w każdym razie jednak, jak sądzi, jest on pierwszym autorem, u którego wyraz ten użyty w liczbie pojedynczej znajduje wyraźne zastosowanie do poszczególnych

17 I (ThWNT) $415 \mathrm{nn}$.

18 Tamże, 436. 
posłańców Jezusa, podczas gdy w synoptycznych Ewangeliach występuje zawsze w liczbie mnogiej ${ }^{19}$.

Jak widać, Rengstorf uznawał tedy za pewny sam fakt przełożenia hebrajskiego šaliach na greckie apostolos, lecz nie chciał nic pewnego twierdzić o czasie, w którym to nastąpiło. Na uwagę zasługuje tutaj jednak hipoteza wskazująca na Antiochię syryjską jako na miejsce, w którym dokonano przekładu z šaliach na apostolos. Śledząc przebieg dyskusji nad nowotestamentalnym apostolatem można zauważyć, że pierwszym autorem, który tę hipotezę postawił, był F. Kattenbusch ${ }^{20}$. Jeśli chodzi o Rengstorfa, to nie jest wykluczone, że przejął on tę hipotezę od Kattenbuscha, na co wskazywałaby ta okoliczność, że w wykazie literatury na temat apostolos wymienia odnośna jego pracę ${ }^{21}$. Bardziej prawdopodobne wydaje się jednak, że Rengstorf nie zauważył u Kattenbuscha. tej hipotezy, wyrażonej zresztą zaledwie w jednym zdaniu w przypisku, i do sformułowania jej doszedł samodzielnie. Hipotezę tę podzielał równocześnie z Rengstorfem $\mathrm{K}$. Lake ${ }^{22}$, następnie po wielu latach odniowili ją jeszcze inni autorzy protestancey, mianowicie H. Mosbech ${ }^{23}$ i W. Schmithals, który przy tym Antiochię syryjską uznał za kolebkę nie tylko wyrazu apostolos, lecz i samej instytucji chrześcijańskiego apostolatu ${ }^{24}$.

Niezależnie od powyższych stwierdzeń niektórzy autorzy sugerują myśl, że Rengstorf również i relację treśaiowo-pojęciową a nawet rzeczową między šaliach a apostolos pojął jako zależność genetyczną. Warto tu przytoczyć kilka wypowiedzi. D. Müller, autor antykułu Apostel, zamieszczonego w ,Theologisches Begriffslexikon zum Neuen Testament” 25, pisze, że według Rengstorfa chrześcijański apostolat zarówno pod względem słownym jak i treściowo-pojęciowym wywodzi się z żydowskiej instytucji šaliach ${ }^{26}$. J. Roloff powiada, że Rengstorf prowadzi prostą linię od późnożydowskiej instytucji šaliach do pojęcia apostolos w Nowym Testamencie ${ }^{27}$. E. Lohse sądzi nawet, że w dociekaniach Rengstorfa, wykorzystującego wcześniejsze prace Kraussa, Vogelsteina i Billerbecka, żydawskie pochodzenie pojęcia apostolatu nie powinno chyba podlegać

19 Tamże

20 F. Kattenbusch, Die Vorzugsstellung des Petrus und der Charakter der Urgemeinde zu Jerusalem, w: Festgabe für K. Müller, Tübingen 1922, 339 przyp. 1.

21 I (ThWNT) $406 \mathrm{w}$ przypisku do apostolos.

22 F. Jackson - K. Lake, The Beginnings of Christianity, V, London 1933, 50.

23 H. Mosbech, Apostolos in the New Testament, ,Studia Theologica", 2 (1949) 188.

24 W. Schmithals, Das kirchliche Apostelamt, Göttingen 1961, 79 nn.

25 Theologisches Begriffslexikon zum Neuen Testament, hrsg. von L. Coenen, I, Wuppertal 1967.

26 Tamże, 34.

27 J. Roloff, Apostolat - Verkündigung - Kirche, Gütersloh 1965, 13. 
wątpliwości ${ }^{28}$. Wresizcie G. Klein utrzymuje, że nie tylko językowa derywacja pojęcia apositiola ale i historyəzne wyprowadzenie tego fenomenu z hebrajskiego šaliach sitanowi decydujące założenie dla tradyøyjnego poglądu o powstaniu i rozwoju chrześcijańskiego apostolatu, który to porgląd przedstawił w najbardziej zwartej koncepcji H. Rengsitorf 29 .

Plowstaje pytanie, czy twierdzenila wymienionych autorów są słusznę i czy odzwierciedlają wiernile pogląd Rengstorfa. Aby odpowiedzieć na to pytanie, należy najpierw zbadać, czy i w jaki sposób autorzy ci udokumentowali siwe twierdzenila.

D. Müller na poparcie swego twierdzenia, iż chrześcijański apostolat także i pod względem treściowo-pojęcliowym wywodzi się według Rengstorfa z żydowskiej instytucji šaliach, nie podaje żadnego odnośnilka do jego rozpraw, co czyni wielokrotnie w dalszym aiagu swego artykułu referując jego poglądy na temat zakotwiozenia chrześcijańskiego apostolatu w życiu Jezusa. W takim razie trzeba do tezy Müllera zastosowac maksymę: Quod gratis asseritur, gratis negatur.

J. Roloff, jak widzlieliśmy, powiada, że Rengstorf prowadizi prostą linię od późnożydiowskiej instytucji šaliach do pojęcia apostolos w Nowym Testamencie. Nasuwa się tutaj od razu pytanie: co to znaczy w tym przypadku ,prowadzi prostą linię"? To obrazowe określenie jest tak wielornaczme, że można pod nie podłożyć różną treść i dlatego właśctiwie niewiele mówi, aczkolwiek sugeruje jakąś zależność między obydwoma tymi pojęciami.

Twierdzenie Lohsego, że po badaniach Kraussa, Vogelsteina, Billerbecka i Rengstorfa żydowskie pochodzenie pojęcia apostolatu nie powinno chyba podlegać wątpliwości, nie mówi wprawdzie wprost, że Rengstiorf do tiakilego wniosku dosizedł, ale w każdym razie sugeruje myśl, ì $z$ taki był rzeəzywiście jego pogląd. Twierdzenie swe wypowiada Lohse również bez bliższego uzasadnienia, wobec tego trzeba je ocenić podobnie, jak tezę Müllera. Można tutaj dodać, że to, oo dla Lohsego nie podlega wątpliwości, nie jest takie pewne dla wielu innych autorów ${ }^{30}$, którzy zapoznali się z wynikami badań leksykologicznych Rengstorfa i jego poprzedników, lecz nie skłoniło ich to do wyprowadzenia wnilosku o zależności i pochodzeniu chrześcijańskiego pojęcia i instytucji apostolatu od żydowskiej instytucji šaliach. Należą do nich tacy badacze ja:

28 E. Lohse, Ursprung und Prägung des christlichen Apostolats, ,Theologische Zeitschrift", Basel, 9 (1953) 260 przyp. 7.

${ }_{29}$ G. Kiein, Die Zwölf Apostel. Ursprung und Gehalt einer Idee, Göttingen $1961,22$.

${ }_{30} \mathrm{~Np}$. W. Schmithals krytykując to twierdzenie Lohsego pisze: ,Nun, dieser Zweifel ist dennoch nicht verstummt, und ich möchte im Gegensatz zu E. Lohse behaupten, dass die spätjüdische Rechtsinstitut mit dem urchristlichen Apostolat nicht das geringste zu tun hat", dz. cyt., $94 \mathrm{n}$. 
A. Ehrhard ${ }^{31}$, G. Sass ${ }^{32}$, H. Mosbech ${ }^{33}$, E. Käsemanin ${ }^{34}$, J. Munck ${ }^{35}$, A. Wickenhauser ${ }^{36}$, W. Schmithals ${ }^{37}$, G. Klein ${ }^{38}$.

Ostatni z wymienicnych tutaj autorów nie uzasadnił również swego twierdzenia o historycznym wyprowadzeniu ,fenomenu apostoła" z żydowskiego šaliach w kcincepcji Rengstorfa. Po sformułorwaniu tego twierdzenia nie daje Klein żadnego odsyłacza do dzieł Rengstorfa. Następnie, powołując się już na konkretne jego wyporwiedıi, zauważa, że konstatujo on istotne różnice zachodzące między obydwiema tymi instytucjami ${ }^{39}$. Dalej, że przestrzega crzed tym, by na podstawie formalnego podoibieństwa nie rozpatrywać ich na jednej płaszczyźnie. Skonstatowanie tych różnic rie przeszkadza jednak Rengstorfowi - jak wywodzi dalej Klein - w przyjęciu twierdzenia o formalnym pokrewiensitwie, a nawet wyraźnym podobieństwie treściowym wymieniionych instytucji ${ }^{40}$, zgodnie $\mathrm{z}$ czym interpretuje cn przekaz synoptyczny wyłącznie pod kątem widzenia instytucji šaliach, rabinistyczne zaś zdanie: „pełnomocnik jakiegoś człowieka znaczy tyle, co sam ów czławiek" podaje wprosit za podstawę nowotestamenitalnego apostolatu ${ }^{41}$.

Przytoczone tutaj przez Kleina wypowiedzi Rengstcrfa nie pozwalają jednak, mimo wszystko, imputować mu tezy o historyoznym wyprowa.dźeniu fenomenu apostoła - jak to określa Klein - $z$ hebrajskiego šaliach. Wiaściwa jego myśl sprowadza się bowiem do zdamia, że obydwie te instytucje mają pewne cechy wspólne, przede wszystkim tę cechę, że šaliach i apostoł są upełnomocnionymi zastępcami. Myśl tę wyrażaja właśnie cytowane przez Kleina wypowiedzi Rengstorfa o formalnym pokrewieństwie obydwu instytucji. W tym zalożeniu staje się też zrozu-

31 A. Ehrhard, The Apostolic Succession in the First two Centuries of the Church, London 1953, $18 \mathrm{nn}$.

32 G. Sass, Apostelamt und Kirche, München 1939, 24.

$33 \mathrm{H}$. Mosbech, art. cyt., $187 \mathrm{n}$.

34 E. Käsemann, Die Legitimität des Apostoles, „Zeitschrift für die neutestamentliche Wissenschaft und die Kunde der älteren Kirche", Giessen, 41 (1942) 51.

35 J. Munck, Paul, the Apostles, and the Twelwe, "Studia Theologica", 3 (1950) 100.

36 A. Wikenhauser, Apostel, w: „Reallexikon für Antike und Christentum”. hrsg. von Th. Klauser, Stuttgart, I, 1941 szp. 555.

37 W. Schmithals, dz. cyt., 92.

38 G. Klein, dz. cyt., 23.

39 Klein wymienia za Rengstorfem następujące różnice: šaliach nie był tytułem żydowskich misjonarzy I ((ThWNT) 418 nn., $432 \mathrm{nn}$.), tytuł ten nie był zastosowany do proroków (s. $420 \mathrm{nn}$.), šaliach $\mathrm{z}$ istoty swej nie miał żadnego odniesienia do sfery religijnej (Apostolat und Predigtamt, 9). Zob. G. Klein, dz. cyt., 49.

${ }^{40}$ W tekście Rengstorfa cytowanym przez Kleina (dz. cyt., 23) użyty jest zwrot Gleichsetzung. Słowo to nie ma adekwatnego odpowiednika w języku polskim $\mathrm{Z}$ kontekstu wynika, że chodzi tutaj o występowanie zarówno $\mathrm{w}$ instytucji šaliach jak i w chrześcijańskim apostolacie pewnych cech wspólnych. Posiadanie cech wspólnych implikuje podobieństwo, dlatego przy pomocy tego bliskoznacznego wyrazu zostaje tutaj oddane niemieckie Gleichsetzung.

${ }^{41}$ G. Klein, dz. cyt., 23. 
miałe, że usiłował on wyjaśnić bliżej naturę nowotestamentalnego apostolatu posługując się analogiami do instytuoji šaliach.

Najbardziej zdecydowanie przemawia jednak przeciwko tezie auto.rów, przypisujących Rengstorfowi wyprowadzenie chrześcijańskiego apostolatu z żydowskiej instytucji šaliach, jego pogląd na właściwą przyczynę powstanila apostolatu. Powstanie to zawdzięcza on, zdaniem jego, Jezusowi Chrystusowi. Do zagadnienia tego wrócimy nieco dalej, tutaj wszakże trzeba jeszcze przedłożyć wywody Rengstorfa na temat zastosowania rzeczownika apostolos w Nowym Testamencie.

\section{APOSTOLOS W NOWYM TESTAMENCIE}

Po przedłożeniu danych statystycznych dotyczących częstotliwości występowania rzeozownika apostolos w poszczególnych księgach Nowego Testamentu wyjaśnia Rengstorf różne jego znaczenia. Zauważa najpierw, że zniknęło w Nowym Testamencie użycie tego słowa w sensie stosowanym zwyczajnie $w$ literaturze pozabiblijnej z Józefem Flawiuszem włącznie. Nie oznacza ono bowiem migdy w Nowym Testamencie aktu posłania lub w przenośnym znaczeniu przedmiotu posłanego, lecz zawsze jest okrreśleniem ezłowieka, który został posłany, czyli posłańca i to posłańca upełnomocnionego. W szczególności w tekście J 13, 16 wymienione słowo jest przekładem omówionego wyżej terminu hebrajskiego i to pojętego czysto prawniczo w sensie pełnomoonika prawomosnie upoważnionego do reprezentowania drugiej osoby i jej sprawy. Wyraz apostolos, podobnie jak šaliach, używany jest następnie na oznaczenie pełnomornika upoważnionego przez gminę. W tym sensie używa go $\mathrm{Pa}$ wel w 2 Kor 8, 23, w zwrocie apostoloi ékklesiōn w odniesieniu do mężów, którzy wieźli do Jerozolimy daniny od greckich gmin. W takim samym znaczeniu Epafrodyt jest wysłannikiem - apostolos - Filipian do Pawła (Flp 2, 25). Z kolei apostołami nazywają się głosiciele nowotestamentalnego orędzia. Wśród nich miano to nosi przede wszystkim krąg Dwunastu, czyli tzw. praapostołowie, łącznie z Maciejem, który wszedł na miejsce jednego z upadłych $(\mathrm{Dz} 1,28)^{42}$. Rengstorf podkreśla, że uży cie słowa apostolos $\mathrm{w}$ takim znaczeniu dominuje $\mathrm{w}$ opisie Łukasza, w jego Ewangelii, a zwłaszczia w Dziejach Apostolskich. Dwunastu jawi się tu po prostu jako apostolowie, jako zamknięte kolegium. Także i w Mt 10, 2 i Mk 6, 30 wyrażenie apostoloi odnosi się według Rengstorfa do dwunastu pierwøzych uczniów Jezusa ${ }^{43}$. Wreszoie apostołami nazywają się prachrześcijańscy misjonarze lub ich najwybitniejsi przedstawiciele, i to także mężowie, którzy nie należeli do szerszego kręgu uezniów Je-

42 I (ThWNT) $421 \mathrm{n}$.

43 Tamże, 422. 
zusa. Rengstorf zwraca uwagę, że nawet w Dziejach Aprostolskich maimv użyte słowo apostoloi w tym znaczeniu, mianowicie w 14, 14, gdzie mianem tym są określeni Paweł i Barnaba. Dwunastu są więc dla Łukasza apostołami, ale krąg ten nie ogranicza się do nich. Należy bowiem do nich przede wszystkim Paweł, który siebie samego nazywa apostołem, szczególniie we wstępach do listów. Dalej, należy do nich także i brat Pański Jakub (Ga 1, 19), który podobnie jak Paweł dopiero po śmierci Jezusa wszedł do gminy chrześcijańskiej, a także Junias i Andronik, dwaj współpracownicy Pawła żydowskiego pochodzenia (Rz 16, 7). Zdaniem Rengstorfa również i w 1 Kor 15, 7 jest mowa o szerszym kręgu apostołów, obejmującym także Jakuba brata Pańskiego ${ }^{44}$.

Rengsitorf widzi różnicę zachodzącą między węższą a szerszą grupą apostołów. Zauważa, jak wspomniano, że do szerszej grupy należeli ci, którzy nie byli uczniami Jezusa; wskazuje również na akt wysłania apositolów grupy szerszej przez gminę (Dz 15, 2 nn.). Sądzi jednakże, że fakt, iż różnica ta nie wyraziła się w odmiennych, własnych nazwach wymienionych grup oraz w przyznaniu im różnej wartości, znajduje swe wytłumaczenie we wspólnej podsitawie apostolatu tych grup, którą stanowi spotkanie ze Zmartwychwstałym i przyjęcie mandatu od Niego samego ${ }^{45}$. Zgodnie $\mathrm{z}$ tym apostołowie z 1 Kor 12, $28 \mathrm{n}$. nie stanowią wcale urzędu gminy, lecz urząd Jezusa budujący Kościół. Z tego tez względu apostołowie wysuwają się na wspólną płaszczyznę ze starotestamentalnymi prorokami (Ef 2, 20; 3, 5), których urząd na podstawie ich posłania był przygotowaniem na ,Nadchodzącego" 46 .

Apostołem jest wreszcie nazwany sam Jezus w Hbr 3, 1. Wyraz , ,apostoł" odniesiony do Jezusa może mieć tu tylko taki sens, że w Nim zostało dokonane objawienie się Boga przez samego Boga ${ }^{47}$.

\section{GeneZa Apostolatu nOWOtestamentalnego}

Rengstorf dostrzega dwa etapy powstania apostolatu. Są nimi ustanowienie apostołów przez Jezusa ziemskiego oraz odnowienie tego aktu przez Chrystusa Zmaritwychwstałego. Według koncepcji Rengstorfa wydarzenia te nie tylko powołały nowotestamentalny apostolat do istnienia, ale i określiły zarazem jego naturę. Przypatrzmy się jednak odnośnym wywodom Regenstorfa bliżej.

Problem powołania apostołów przez Jezusa ziemskiego poprzedza Rengstorf uwagami na temat stosunku zachodzacego między grupami osób oznaczonymi w Nowym Testamencie wyrażeniami „uczniowie”

\footnotetext{
44 Tamże.

45 Tamże, 423.

46 Tamże.

47 Tamże.
} 
(mathètai) — „Dwunastu” (dodeka) — „apostołowie” (apostoloi). Zagadnienie to omawia szerzej $\mathrm{w}$ osobnym artykule $\mathrm{w}$ ThWNT pt. dōdeka

Wyrażenie ,uczniowie" stanowi, według Rengstorfa, określenie ogólniejsze. Oznaczeni w ten sposób tworzą większą wspólnotę, przy czym mogą oni nie być ani apostołami ani Dwunastoma. Apostoł jest zawsze uczniem, lecz nie każdy uczeń musi być apostołem. Zwrot ,dwunastu apostołów" nie pociąga kcrieczności utożsamienia Dwunastu z apostołami; przeciwnie, połączenie tych wyrażeń tożsamość taką nawet wyklucza ${ }^{48}$.

Formuły „dwunastu uczniów” (np. Mt 10, 1), „dwunastu apostołów” (Mt 10, 2; Łk 22, 14) i „Dwunastu” (Mt 26, 14) pokrywają się — jak powiada Rengstorf - ze sobą w odniesieniu do osób, ale nie co się tyczy samej rzeczy, gdyż nie wszyscy uczniowie są apostołami, lecz tylko ci, których Jezus wyraźnile do tego przeznaczył. U początków tego kręgn, określanego później zawsze zwrotem „Dwunastu” nastąpil bowiem oparty na decyzji wolnej woli Jezusa wybór spośród tych, którzy przyłączyli się do Niego. Z wyborem tym związany jest apostolski udzial w urzędzie i działalności Jezusa ${ }^{49}$.

6. DYSKUSJA WOKÓ PROBLEMU POWOEANIA DWUNASTU APOSTOEOW a. H. RENGSTORF

Rengstorf bardzo zdecydowanie opowiada się za historycznością powołania ziemskiego Jezusa dwunastu apostołów. Odrzucenie tego aktu czyni zdaniem jego niezrozumiałym istnienie wymienicnej grupy w pragminie chrześcijańskiej, natomiast uznanie go w oparciu o relacje syncptyków wyjaśnia ich w niej obecność i szczególne stanowisko. Rengstcrf uważa, że usiłowanie wyjaśnienia powstania kolegium Dwunastu w ten sposób, jak to uczynił $m$. in. R. Schütz ${ }^{50}$, wyznaczający początek ich istnienia na okres między śmiercią Jezusa a nawróceniem Pawła, ma przeciwko sobie poważne zanzuty. Niewyjaśnionym jest witedy, po pierwsze, w czym tkwią motywy tego, że właśnie owych dwunastu męźów wyrasta w autorytatywną grupę, skoro jest faktem nie tylko istmienie większego kręgu uczniów, lecz także i okoliczność, że nie mogli oni rościć sobie pretensji do posiadania wyłącznego przyiwileju spotkaria ze Zmartwychwstałym lub choćby tylko spotkania z Nim w szczególny sposób. Po wtóre fakt, że prachrześcijańska tradycja uznaje zdrajcę Judasza za pochadzącego z kręgu Dwunastu (Mt 26, 14. 47), przemawia za istnieniem wymienionej grupy już w ozasach przed śmiercią Jezusa, co poświadcza również Paweł wymieniając obok Piotra

\footnotetext{
4 Tamże, 425.

49 Tamże, II, 325.

50 R. Schütz, Apostel und Jünger, Giessen 1921, 76.
} 
Dwunastu jako pierwszych świadków zmartwychwstania (1 Kor 15, 5) i przyznając im przez to miejsice wyrażające ich szczególne powiązanie z Jezusem. Po trzecie wreszcie, tradycja w odniesieniu do czasu między śmiercią Jezusa a wyborem Macieja mówi o „Jedenasitu” (uczniów, apostołów): Mt 28, 16; Mk 16, 14; Łk 24, 9. 33; Dz 1, 26), co byłoby wprost bezsensowne, gdyby Dwunastu nie stanowili dla niej grupy pochodzącej z czasów przed śmiercią Jezusa. Całą tę tradycję musiałoby się uznać za mistyfikację lub legendę, gdyby Dwunastu stanowili wytwór pragminy jerozolimskiej ${ }^{51}$.

Pcwołanie uczniów na apostołów wiąże Rengsitorf $\mathrm{z}$ rozesłaniem ich na misję w czasie ziemskiego życia Jezusa. Wskazuje przy tym na okoliczność, że akt ten opisuje Marek przy pomocy czasownilka apostellein, podczas gdy Mateusz i Łukasz, a w drugiej relacji także i Marek, jako cechę wyróżniającą tego aktu podkreślają wyposażenie w moc - eksousia, która przysługiwała samemu tylko Jezusowi. Zdaniem Rengstorfa widać stąd, że chodzi tutaj o autorytatywne posłanie w sensie upełnюmocnienia, tak że wysłanych w ten sposób mężów należy uważać za šeluchim 52 .

Problemu, czy rozesłanie Dwunastu jest historycznym aktem Jezusa, czy też ma się je uważać tylko za późniejszy wymysł, wynikłego stąd, że chciano dowieść, iż kolegium dwunastu apostołów pragminy zostało autoryzowane przez slamego Jezusa za czasów Jego ziemskiego życia, nie chce Rengstorf bliżej roztrząsać. W każdym razie uważa, że problem ten $w$ takiej formie został chyba fałszywie postawiony, gdyż zakłada on możliwość, o ile nawet nie konieozność, utożsamienia Dwunastu z apostołami, za czym zwolennicy tego poglądu nie mogą przytoczyé żadnej racji poza formulami, ktćre wszakże mogą być inaczej wyjaśnione. W związku z tym Rengstorf sądzi, że historyczne powiązania rzeczy stają się jeszcze bardziej niejasne, jeśli skreśli się rozesłanie Dwunastu przez Jezusa ${ }^{53}$.

Sprowadzenie apostolatu Dwunastu do samego Jezusa nie jest jednak, zdaniem Rengsitorfa, uzależnione od spornego faktu ich rozesłania. Mamy bowiiem, jak sądzi, dwa świadectwa, przemawiające za istnieniem apostolatu na sposób żydowskiej instytucji šaliach. Pierwsze

51 II (ThWNT) 325. Rengstorf dodaje tutaj, że J. Wellhausen (Einleitung in die drei ersten Evangelien, ${ }^{2} 1911,144$ n.) poszedł tak daleko, iż odrzucił jako niehistoryczną przynależność Judasza do kręgu Dwunastu, przeciwko czemu E. Meyer (Ursprung und Anfänge des Christentums, I, Stuttgart 1921, 296) wytoczył zarzut, że w takim razie Wellhausen musiałby także i relację o wyborze Macieja uznać za niehistoryczną, bowiem założywszy tezę Wellhausena należałoby przyjąć, że Maciej należał do Dwunastu od początku, albo że stanowi fikcję. Zob. II (ThWNT) 326 przyp. 41.

52 I (ThWNT) 425.

53 Tamże, $425 \mathrm{n}$. 
z nich znajduje się w Mk 9, 38 nn.; Łk 9, 49. Z przytozzonej tutaj wypowiedzi Jana wynika, że według niego upoważnionymi do wyrzucania demonów są jedynie uczniowie Jezusa. Takie przeświadczenie było, zdaniem Rengsitorfa, możliwe tylko wiedy, jeśli upoważnienlie do spełniania nadzwyczajnych znaków nie było jedynie pobożnym życzeniem, lecz było rzeczywistością, tzn. zostało dane przez Jezusa Jego uczniom.

Drugie świadectwo stanowią, według Rengstorfa, słowa Jezusa wyrażające myśl, jakie znaczenie dla samych uczniów ma sposób traktowania ich przez ludzi (Mt 10, 40 nn.; Mik 9, 41; Łk 10, 16). Zakładlaja one zasadę, że šaliach jakiegoś człowieka znazzy tyle, co sam ów czło wiek, d że czyn spelniony wobe乞 pelnomonnika šaliach ma taka samą wartość, jakby był spełniony wobec jego monodawey. Słowa te, jak sądzi Rengstorf, były jednak możliwe tylko wtedy, jeśli zostało już dane odpowiednie upełnomocnienie tym, o których jest tu mowa.

Obydwa te miejsca, jak konkluduje ostatezznie Rengstorf, potwierdzają fakt autoryzasji w kręgu uczniów Jezusa i to tym bardziej, że ja suponuja, lecz nie mają zamiaru jej uzasadniać ${ }^{54}$.

W przedłożonych powyżej wywodach Rengstorfa można wyróżnić dwa różne, aczkolwiek pozostające ze sobą w ścisłym związku zagadnienia. Chodzi mianowicie o zagadnienie historyczności akstu ukonstytuowania przez ziemskiego Jezusa kolegium Dwunastu oraz o zagadnienie aktu powołania przez Niego apostołów. Zagadnienia te, rozpatrywane pierwotnie najczęściej łącznie, tj. w formie pytania o historyczność powołania dwunastu apostołów, mają również swą długą historię. Pierwszy zanegował historyczność tego aktu F. Schleiermacher 55, za któryn opowiedzieli się nieliczni radykalniejsi protestanccy autorzy ${ }^{56}$. Większość uznawała natomiast historyezność powolania Dwunastu, jednakże wielu zaczęło kwestionawać ustanowienie ich apostołami ${ }^{57}$. Taki stan rzeczy trwał w obozie protestanckim prawie bez zmiany do lat dwudziestych naszego stulecia, kiedy to nastal okres tzw. antykrytyki. Przedstawiciele tego okresu zaakcentowali stanowisko prawne apostołów, przyjmując zarazem zdecydowanie historyczność ich ustanowienia przez ziemskiego Jiezusa. Do tych to, pocieszających dla strony kiatolickiej, rezultatów badawczych, ,antykrytyki" dochodzi z kolei gios poważnegi) protestanckiego uczonego, H. Rengstorfa, który, jak widzieliśmy, nie tyl-

54 Tamże, 426.

55 F. Schleiermacher, Ueber die Schriften des Lukas. Ein kritischer Versuch, w: Friedrich Schleiermacher's sämtliche Werke, cz. 1: Zur Theologie, t. 2, Berlin 1836,62 .

56 Zob. W. Seufert. Der Ursprung und die Bedeutung des Apostolates in der christlichen Kirche der ersten zwei Jahrhunderte, Leiden 1887, 19; J. Wellhausen, dz. cyt., 138 nn.; R. Schütz, dz. cyt., 72 nn.; por. O. Linton, Das Problem der Urkirche in der neueren Forschung. Eine kritische Darstellung, Uppsala 1932, 73.

${ }_{57}$ E. Haupt. Zum Verständnis des Apostolats im Neuen Testament, Halle 1895-1896, 107; H. Monnier, La notion de l'apostolat des origines à Irenée, Paris 1903. 
ko opowiada się zdezydowanie za history znością ustanowienia przez Jezusa zarazem Dwunastu jak i apostołów, lecz nadto usiłuje swe twierdzenia poprzeć argumentami. Będzie przy tej okazji rzeczą pożytezzną wskazać, jakie stanow: ko zajęła w tej sprawia późniejsza krytyka protestancka.

Autorów protestanckich zajmujących się po publikacjach Rengstorfa z r. 1933 zagadnieniom apostolatu nowotestamentalnego można podzielic na trzy grupy. Najlizzniejsza $z$ nich, reprezentowana przez takizh autorów jak W. Kummel ${ }^{58}$, H. Campenhausen ${ }^{59}$, A. Fridrichsen 60, J. Munzk 61, E. Lohse ${ }^{62}$, uznaje historyezność ustanowienia Dwunastu wzglęłnie małej grupy uczniów przez ziemskiego Jezusa, jednakże przypisuje jej pewną formę działalności apostolskiej, tj. w danym wypadku misjonarskiej, doplero po Wielkanocy, przy czym Pawia uważa za właściwego twórce nazwy "spostol" i w ogóle chrześaijańskiergo pojęia apostola ${ }^{63}$. Drugą, nieliczną grupe stanowią najbardziej radykalni badacze, należący do racjonalistycznego kierunku szkoły $R$. Bultmanna. Głównymi jej przedstawicielami sa cytowani już G. Klein i W. Schmithals oraz P. Vielhauer ${ }^{64}$, którzy zarówno odrzucaja historyzzność aktu ukonstytucwania dwunastu uczniów przez ziemskiego Jezusa jak i odmawiaja im wszelkich cech apostolskich i to nie tylko w odniesieniu do czasów przed Wielkanocą, lecz i po niej. Do trzeciej, nielicznej również grupy, zaliczają się wszyscy ci, którzy bronią zarówno historyczności jak i apostolsikośai Dwunastu. W grupie tej wyróżniają się szczególnie autorzy: C. Cullmann ${ }^{65}$, C. Barrett ${ }^{66}$, B. Gerhardision ${ }^{67}$.

\section{b. G. Klein}

Szczególową krytykę przedłożonych wyżej argumentów Rengstonfa za historycznością kolegium Dwunastu podczas ziemskiego życia Jezusa oraz za ich charakterem apostolskim przeprowadził G. Klein. Rozpoczy-

${ }_{5 *}$ W. Kümmel, Kirchenbegriff und Geschichtsbewusstsein in der Urgemeinde und bei Jesus, Zürich 1943. 30.

59 H. Campenhausen, Kirchliches Amt und geistiche Vollmacht in den ersten drei Jahrhunderten, Tübingen 1953, 15.

60 A. Friedrichsen, The Apostle and his Flessage, Uppsala 1947, 8 przyp. 12.

61 J. Munck, art. cyt., 104. 108.

62 E. Lohse, art. cyt., 262.

63 Por. J. Giblet, Die Zwölf: Geschichte und Theologie, w: Giblet J. (hrsg.), Vom Christus zur Kirche. Charisma und Amt im Christentum, Wien 1966, 64.

${ }_{64} \mathrm{P}$. Vielhauer, Gottesreich und Menschensohn in der Verkündigung Jesu, w: Festschrift für G. Dehn, Neukirchen 1957, 51-80.

65 O. Cullmann, Petrus, Jünger — Apostel - Märtyrer, Zürich 1952, 247.

66 C. Barrett, The Apostles in and after the New Testament, ,Svensk exegetisk Ärsbok", Uppsala, 21 (1957) 46.

${ }_{67}$ B. Gerhardsson, Die Boten Gottes und die Apostel Christi, ,Svensk exegetisk Ärsbok", 27 (1962) 101 nn. 
na ją od ataku na apositolskość Dwunastu. A oto jak pnzedstawia się tok jego wywodów.

Twierdzenie o zakotwiczeniu instytucji apostołów i pojęcia apositoła w dziejach Jezusa opiera się, zdaniem Kleina, na rzekomo bliskim pokrewieństwie między instytucją šaliach a strukturą kręgu uczniów, zgromadzonych wokół historyaznego Jezusa. Takie polkrewieństwo jest jednak, jak sądzi, bardzo nieprawdopodobne, ponadto teksty, które Rengstorf przytacza, nie sitanowią dowodu wymienionego twierdzenia.

Klein analizuje je po kolei.

Tekst Mk 9, 38 nn. par. ma dowieść, że w kręgu uczniów doszla do skutku autoryzacja przez Jezusa na wzór autoryzacji pełnomocnika zwanego šaliach. Jednakże, zdaniem Kleina, absitrahując od problemu autentyczności wymienionego tekstu, trzeba przyjąć, że mówi on o czymś wręcz przeciwnym. Przeciwstawiając wyrażenie poiein dynamin epi tö onomati Jesou (spelniać cuda w imię Jezusa) słowom kakalogein Jesoun (źle mówić o Jezusie) relatywizuje bowiem ów tekst wszelką formalna autoryzację i odrzuca wszelką refleksję, która by prawomocność powoływania się na Jezusa oceniała przy pomocy innego kryterium, niz kryterium treśai. Bynajmniej nie można przy tym utrzymywać, że wysitąienie Jana wypłynęło z błędnego i następnie skorygowanego przez Jezusa założenia konieczności autoryzacji kręgu uczniów. Bowliem Jan krytykuje nie brak upoważnienia egzorcysty przez Jezusa, lecz — jak tego od czasćw Wellhausena ${ }^{68}$ nie wolno zapominać — brak jego łąozności z apositołami 69 .

Drugi argument za zakotwiczeniem apostolatu w życiu Jezusa oparty jest u Rengstorfa, jak widzieliśmy, na tekstach Mk 9, 41; Mt 10, 40 nn.; 乇k 10, 16. Klein przytacza najpierw wyniki badań przeprowadzone metodą Formgeschichte co do wymienionych tekstów i powiązania ze sobą poszczególnych ich wierszy. Zdaniem Kleina R. Bultmann 70 wykazał, że w Ewangelii Marka w rozdziale 9 wiersz 41 związany jest z wierszem 37, podczas gdy wiersze 38-40 są interpolowane; podobnie "v Ewangelii Mateuszla w rozdziale 10 wiersz 40 stanowi całość z wierszem 42, zaś wiersz 41 jest intempolowany. W obydwu ujęciach wyrażenie paideia (dziezi, Mk 9, 37), względnie mikroi (maluczcy, Mt 10, 42) - jak w oparaiu o badania metodą Formgeschichte sądzi Klein — jest pierwotne w stosunku do zwrotu hymeis (wam, Mk 9, 41) i należy je rozumieć w znaczeniu właściwym, a nie przenośnym. Wszystko to prowadzi, według Kleina, do wniosku, że jeśli w wymienionych tekstach uczeń utcżsamiony jest z Jezusem, to może tu chodzić jedynie o reprezentowanie Zmartwychwsta-

68 J. Wellhausen, Das Evangelium Marci, Berlin ²1909,, 81.

69 G. Klein, dz. cyt., 28.

${ }^{70}$ R. Bultmann, Die Geschichte der synoptischen Tradition, Göttingen ${ }^{7} 1967,152$. 
lego, a nie Jezusa ziemskiego. Nadto, jak dodaje, zauważony przez egzegetów Janowy styl wiersza Mk 9, 40 b stanowi dalszy dowód, że zdanie w nim wypowiedziane jest wyrazem refleksyjnej świadomości gminy. Wreszcie jeśli Łk 9, 16 stanowi dowód dla tezy Rengstorfa, to według Bultmanna ${ }^{71}$ tekst ten stanowi tylko przytoczony przez Marka twór gminy chrześcijańskiej, którego strukturę o cechach judaistycznych należy rozumieć w oparciu o instytucję šaliach. To stanowisko Bultmannia niezbyt jednak zadowala Kleina, negujązego, jak widzieliśmy, wszelkie pokrewieństwo między instytucją šaliach a strukturą kręgu uczmiów Jezusa. Toteż zauważa, że nie jest to jedyna możliwa interpretacja metodą Formgeschichte. Sądzi, że słowa Łk 10, 16 przedstawiają drugi etap na drodze chrystianizacji żydowskiego aforyzmu o dzieciach: podczas gdy teksity Mt 10, 40 nn. i Mk 9, 41 zmodyfikowały na modłę chrześcijańską jedynie przedmioty dobrych uczynków, to Łk 10,16 chrystianizuje juz chyba sam dokry uczymek 72 .

W odniesieniu do przedlożonej tu krytyki argumentacji Rengstorfa przez Kleina nasuwa się kilka uwag. Najpienw co się tyczy argumentu pierwszego trudno zgodzić się w zupełności z Kleinem, gdy utrzymuje, że tekst przytaczony przez Rengstorfa na poparcie jego tezy, mówi o czymś wręcz przesiwnym. Można się zgodzić jedynie na to, że odpowiedź Jezusa dana Janюwi relatywizuje wszelką formalną autoryzację. Ale, po pierwsze, już to twierdzenie implikuje możliwość autoryzacji nieformalnej. Jeśli bowiem egzorcysta wyrzucający czarty w imię Jezusa działał Jego moca, to zakłada to mimo wszystko pewien rodzaj autoryzacji, którą można by nazwać autoryzacją nieformalną. Z tego nie wynika jednak, że uczniowie nie otrzymali formalnej autoryzacji. Pytanie, czy dany tekst tego dowodizi, to już inna sprawa, miesłuszny jest jednak zbyt pochopny wiliosek Kleina, że wymieniony tekst dowodzi czegós wręcz przeciwnego.

Należy z kolei rozważyć, czy słuszne jeș w całej rozciągłości twierdzenie Wellhausena, na które się Klein pawołuje, że Jan w swym wystąpieniu krytykuje nie brak upoważnienia egzorcysity ze strony Jezusa, lecz brak jego łąozności $\mathrm{z}$ apostoł’ami. Te dwie rzeczy, jak się wydaje, nie wykluczają się wzajemnie. Wchodzą tu w grę dwie możliwości. Po pierwsze jest niewykluczone, że Jan był przekonany, iż postępowanie egzorcysty zasługuje na naganę dlatego, bo nie pozostaje on w lązzności z apostołami, przy czym ewangelistta suponował brak wszelkiej, a więc nie tylko formalnej autoryzacji egzoncysty. W takim wypadku należałoby przyjąć, że wypędzanie czartów przez egzorcystę pojmorwalby on na sposób magiizny: samo wezwanie imienia Jezusawego, bez duchowej

i1 Tamże, 153.

72 G. Klein, dz. cyt., $30 \mathrm{nn}$. 
z Nim łączności, bez udzielenia odpowiedniej mocy i bez żadnej autoryzacji, miałoby sprowadzać skutek. Gdylby Jan w ten sposób rzecz rozumiał, to nie wykluczałoby to jednak bynajmniej, że autoryzacja do wypędzania czartów została dana przez Jezusa: formalna uczniom - nieformalna egzorcyście.

Bardziej prawdopodobna jest jednak możliwość druga. Bultmann nie udowodnił w sposób pewny twierdzenia, że zwrot en onomati Jesou powstał dopiero iw pragminie chrześcijańskiej; możliwe jest, że zwrot ten nie oznaczał wezwania imienia Jezusowego, lecz wystącienie po Jego stronie. W takim razie interwenoję Jana należałoby wszakże tłumaczyc tak, jak to właśnie czyni Rengstorf: ewangelista oburza się, że egzorcysta wypędza czarty mocą Jezusa, nie będąc do tego upoważnionym.

Co do oceny przez Kleina drugiego argumentu Rengstorfa trzeba poczynić również kilka zastrzeżeń. Pierwsze z nich dotyozy sprrawy ustalenia autentyczności i wzajemnego pawiązania tekstów cytowanych w tym argumenaie. Otóż wnioski, do jakich w tej sprawie w oparciu o metodę Formgeschichte doszedł Bultmann, mogą sobie rościć pretensje jedynie do prawomocnej hipotezy. Tak zresztą traktuje rzecz sam Bultmann, który wyraża się tutaj ostrożnie ${ }^{73}$. Klein traktuje jednak te prawdopodobrie wnioski Bultmanna jako pewnik, ráwny ścisłemu dowodowi.

Drugie zastrzeżenie, jakie pod adresem wywodów Kleina należy uczynić, odnosi się już do samego sedina sprawy, to jest do oceny wartości argumentacji Rengstorfa. Wydaje się, że wywody Kleina, zwłaszcza zaś zarzuty wysunięte przeciwko ảrugiemu argumentowi nie połważają calkowicie wartości tej argumentacji, jednakże znacznie osłabiają jej siłę dowodową. W świetle wysuniętych zastrzeżeń argumenty te zdają się dowodzić jedynie w sposób prawdopodabny. To stwierdzenie prowadzi do następnego pytania: czy uprawnione są wabec tego ostateczne wnioski, jakie Klein w tej sprawie wyciągnął, gdy mianawicie po zakończeniu swej oceny ,konserwatywnego consensus" pisał, że „synoptyczna tradycja nie dostarcza żadnego pewnego pod względem krytyoznym dowodu za istnieniem - ad interim czy na dłuższy okres - apostołów w onszaku historycznego Jezusa". Otóż należy tu zauważyć, że autorzy oporwiadający się za zakotwiczeniem apostolatu w życiu ziemsikim Jezusa opieraja się raczej na innych danych tradycji, niż to uczynił Rengstorf. Zreszta cn sam W rozprawie poświęconej wyborowi Macieja na apostoła ${ }^{74}$, opublikowanej już po II wojnie światowej, oparł się również na innych argumentach. Do sprawy tej trzeba będzie wróoić nieco dalej, wpierw jed-

73 Np. na s. 152 cytowanego wyżej dzieła Bultmann pisze: „Das Verhältnis von Mk 9, 37 - 41 und Mt 10, 42 scheint mir zu zeigen, dass Mk 9, 37. 41, Mt 10, 40, 42. zusammengehören”, podobnie na s. 153: „Das Verhältnis von Lk 10, 16 zu dem Mk-Mt-Wort scheint mir dies zu sein".

it H. Rengstorf, Die Zuwahl des Matthias, $45 \mathrm{n}$. 
nak wypada przebadać drugą część wywodów Kleina dotyczących oceny argumentacji Rengstorfa za istnieniem kolegium Dwunastu w okresie ziemskiego życia Jezusa.

Klein przyznaje, że jeśli faktem jest, iż wśród przedstawicieli „konserwatywnego consensus" są różne zdania na temat zakotwiczenia apo-stolatu $\mathrm{w}$ ziemskim życiu Jezusa, to jednak wielu z nich opowiada się za historyoznością Dwunastu w tym czasie. Argumenty wysuwane przez nich za tą tezą nazywa Klein stereotypowymi. Za W. Kümmelem ${ }^{75}$ wymienia następnie owe ,stereotypowe argumenty”, z których kilka przytacza również Rengstorf. Należą do nich: 1 Kor 15, 5; postać Judasza zárajcy jako członka kolegium Dwunastu; jednorazowe tylko wymienie-rie tej instytucji w Dziejach Apostolskich; relacja o wyborze Macieja; Mt 19, 28 par. Według Kleina, przy bliższej obserwacji ujawnia się słabość każdego z tych argumentów. Co więcej, jeden z nich, tj. 1 Kor 15, 5, przez wzmiankę o dwunastu zamiast o jedenastu świadkach, dowodzi czegoś wręoz przeciwnego, jak to wykazał P. Vielhauer ${ }^{76}$. Wprawdzie, zauważa Klein, E. Bammel uważa zwrot „Dwunastu” w tym miejseu za nazwę urzędowego kolegium, którego liczba nie była często pełna ${ }^{77}$, podolnie E. Lichtenstein mówi o ,jedenastu mężach dwunastki" (elf Zwölfmänner) ${ }^{78}$. Takie thumaczenie nie zadowala jednak Kleina, który jest zdania, że należałoby poddać je pod dyskusję, o ile istnienie tego rodzajui instytucji przed wydarzeniami wielkanocnymi byłoby dowiedzione na innej drodze ${ }^{79}$.

Chcąc ocenić wartość rozumowania Kleina trzeba najpierw zapoznać się z argumentacją Vielhauera, na której krytyk Rengstorfa się opiera i zapytać, czy rzeczywiście autor ten dowiódł prawdziwości swej tezy.

Argumentacja jego sprowadza się czterech następujących zdań: „Przeciwko istnieniu kręgu Dwunastu za życia Jezusa przemawia przede wszystkim stara, przypuszczalnie palestyńska formuła 1 Kor 15, 3-5; według niej Zmartwychwstały ukazał się najpierw Kefasowi, potem Dwunastu, natomiast według Ewangelii (i Dziejów Apstolskich) mogło być tylko Jedenastu (ponieważ Judasz odpadł, a Maciej nie został jeszcze wybrany). Albo tedy paradosis 1 Kor 15 ma rację, albo opis ewangelistów. Że stare wyznanie wiary mówiło o Dwunastu, podczas gdy w rzeczywistości chrystofania nastąpiła tylko wobec Jedenastu, uważamı za wykluczone, ponieważ termin 'Dwunastu' oznacza jednorazowy, historyczny krąg osób, nie trwałą instytucję, której nazwa mogła być użyta

is G. Kümmel, dz. cyt., 30 n.

76 P. Vielhauer, art. cyt., 62.

77 E. Bammel, Herkunft und Funktion der Traditionselemente in 1 Kor 15, 1-11, ,Theologische Zeitschrift”, 11 (1955) 405 przyp. 20.

i\& E. Lichtenstein, Die älteste christliche Glaubenformel, ,Zeitschrift für Kirchengeschichte", Stuttgart, 63 (1950/51) 35 przyp. 136.

79 G. Klein, dz. cyt., $34 \mathrm{n}$. 
bez względu na kompletność stanu liczebnego jej członków, a więc w znaczeniu czysto formalnym. Jeśli jednak zjawienie Zmartwychwstałego nastąpiło rzeczywiście wobec dwunastu, a nie jedenastu byłych uczniów, to zostali oni właśnie przez to zjawienie ukonstytuowani jako zamknięty krąg Dwunastu" 80.

W odniesieniu do argumentacji Vielhauera nasuwa się kilka zastrzeżeń. Po pierwsze, zakłada on a priori, że zjawienie, o jakim pisze Paweł w 1 Kor 15,5, dokonało się przed wyborem Macieja. Wszakże nie jest̂ to pewne; możliwe jest również, że zjawienie to nastąpiło po wyborze Macieja, a więc dokonało się faktycznie wobec Dwunastu. Jeśli jednak zjawienie dokonało się przed wyborem Macieja, to i tak nie dowodzi to, że Dwunastu nie istnieli już jako kolegium przed śmiercią Jezusa, gdyż wyrażenie „Dwunastu” w 1 Kor 15, 5 może faktycznie oznaczać kolegium, którego skład w określonym czasie nie musiał być pełny. Za taką możliwością opowiadają się nie tylko autorzy katoliccy ${ }^{81}$, lecz równièz i protestanccy, m. in. wymienieni przez Kleina. Fakt, iż większość przekazów pierwotnej kerygmy mówi o zjawieniu Zmartwychwstałego przed Jedenastoma (Mt 28, 16; Łk 24, 9. 25; Mk 16, 14), wskazuje natomiast na to, że istnieli oni już wtedy jako zwarta grupa, co w łączności $z$ opisem zdrady Judasza i wyboru Macieja stanowi świadectwo dowodzace ukonstytuowania kolegium Dwunastu już w okresie ziemskiego życia Jezusa. Nierealna jest tedy alternatywa wysunięta przez Vielhauera, ż albo paradosis 1 Kor $15 \mathrm{ma}$ rację, albo opis ewangelistów, bowiem w oparciu o podane argumenty jest widoczne, że 1 Kor 15, 5 pozostaje $\mathrm{z}$ wymienionym opisem $\mathrm{w}$ zupełnej zgodności. Wreszcie nieuzasadnione jest stanowisko Vielhauera, który wyklucza możliwość, że wyznanie wiary mówiło o chrystofanii wobec Dwunastu, a zjawienie się Chrystusa nastapił faktycznie wobec Jedenastu. Wykluczenia takiego dokonuje bowiem Vielhauer w oparciu o przyjęte bez dowodów założenie, uznające termin „Dwunastu” za oznaczenie jednorazowego, historycznego kręgu osób, a nie trwałej instytucji. Co więcej, założenie to stoi w wyraźnej sprzeczności z tradycją synoptyczną, a zwłaszcza z przekazem Mk 3, 14.

Włączenie przez prachrześcijańską tradycję zdrajcy Judasza do kolegium Dwunastu nie stanowi, zdaniem Kleina, również argumentu za ukonstytuowaniem tegoż kolegium w czasie ziemskiego życia Jezusa. Klein wymienia inne możliwości wytłumaczenia tego faktu, wysunięte przez hipotezy różnych autorów. Tak np. P. Vielhauer utrzymuje, że włączenie Judasza do kolegium Dwunastu da się uczynić zrozumiałym także przy założeniu powielkanocnego powstania tego kręgu. Chociaż

80 P. Vielhauer, art. cyt., 62.

81 Zob. B. Rigaux, Die "Zwölf" in Geschichte und Kerygma, w: Ristow H. Matthiae K. (red.), Der historische Jesus und der keryg matische Christus, ${ }^{21961,} 479$. 
bowiem nie ma wątpliwości co do tego, że jeden z uczniów zdradził Jezusa, to również jest pewne, iż najstarsza gmina chrześcijańska poradzila sobie z tym gorszącym zajściem, uzasadniając zdradę wolą Bożą $(\mathrm{Mk} 14,21)^{82}$. Z kolei E. Barnikol 83 i W. Schmithals ${ }^{84}$ wysuwają hipotezę, że dopiero w powielkanocnym kręgu Dwunastu doszło do sensacyjnego wypadku odszczepieństwa, które następnie w postaci opowiadania o zdrajcy Judaszu oraz o kolegium Dwunastu zostało przerzucone wstecz na ziemskie życie Jezusa. Zdaniem Kleina, jest rzeczą obojętną, która z wymienionych możliwości by się przyjęło; ważnym jest natomiast, że wskazanie na zdraję $w$ tym mniejszym stopniu dowodzi koncepcji konserwatywnego consensus, im więcej jest możliwych do pomyślenia różnych logicznie alternatyw ${ }^{85}$.

Można by tutaj odpowiedzieć Kleinowi, że rzeczywiście istnieje możliwość podania prawie nieograniczonej liczby tłumaczeń zdrady Judasza $\mathrm{w}$ inny sposób, niż to czyni tradycja synoptyczna. Tylko że nie widać powodu, dlatego mielibyśmy wierzyć raczej owym tłumaczeniom, niż ewangelicznej tradycji, której wiarygodność odrzuca się za każdym razem, kiedy chce się ze wszelką cenę dowieść słuszności postawionej przez siebie tezy z ową tradycją niezgodnej. Dodać tu można, że argument oparty na opisie zdrady Judasza, zwłaszcza jeśli rozpatruje się go w powiązaniu z innymi argumentami, przemawia za istnieniem kolegium Dwunastu w okresie ziemskiego życia Jezusa nie tylko zdaniem teologów ka-tolickich, lecz także i wielu uczonych protestanckich ${ }^{86}$.

Kolejny argument oceniany krytycznie przez Kleina opiera się na fakcie jednorazowego wymienienia Dwunastu w Dziejach Apostolskich $(6,2)$. Odwołując się do tego faktu W. Kümmel wnioskował, że byłby or trudno wytłumaczalny, gdyby grupa Dwunastu powstała dopiero w pragminie, a nie w czasach ziemskiego życia Jezusa ${ }^{87}$. Zdaniem Kleina, liczba wzmianek o Dwunastu jest tylko pozornie mała, gdyż na 29 miejsc, które w Dziejach Apostolskich mówią o apostoloi, w dwudziestu siedmiu chodzi o należących do instytucji Dwunastu. Po wtóre, z częstotliwości wzmianek o Dwunastu w Dziejach Apostolskich nie można w ogóle niczego wnioskować o stosunkach w najstarszej gminie, gdyż księga ta zawiera tylko fragmenty autentycznej tradycji z tych czasów. Po trze-cie wreszcie, nie można zrozumieć, w jaki sposób milczenie (pozorne) o Dwunastu ma stanowić mniejszą zagadkę, przy założeniu ich zakotwi-

82 P. Vielhauer, dz. cyt., 63.

83 E. Barnikol, Das Leben Jesu der Heilsgeschichte, 1958, 332. Cytuję za: G. Klein, dz. cyt., 36 przyp. 140.

${ }_{84}$ W. Schmithals, dz. cyt., $58 \mathrm{n}$.

85 G. Klein, dz. cyt., 36 przyp. 140.

86 Zob. np. W. Kümmel, dz. cyt., 30.

87 Tamże. 
czenia w ziemskim życiu Jezusa, niż przy opowiedzeniu się za ich powstaniem po Wielkanocy ${ }^{88}$.

Zastrzeżenia krytyczne Kleina w tym wypadku wydają się być o tyle słuszne, że - jak wskazał - w Dziejach Apostolskich faktycznie wiele razy jest mowa o Dwunastu, mimo że tylko jeden raz, tj. w 6, 2 określeni są wyraźnie tym mianem. W mniejszym stopniu należy natomiast przyznać Kleinowi rację, gdy twierdzi, że milczenie o Dwunastu nie stanowi mniejszej zagadki przy opowiedzeniu się za ich zakotwiczeniem w ziemskim życiu Jezusa niż przy opowiedzeniu się za ich powstaniem po Wielkanocy. Jest bowiem chyba rzeczą zrozumiałą, że Łukasz poświęcilby więcej uwagi w swych Dziejach Apostolskich instytucji powstałej w czasach przez niego opisywanych i sprawującej wtedy rolę kierowniczą w pragminie chrześcijańskiej.

Krótko rozprawia się Klein z pozostałymi argumentami ,konserwatywnego consensus". Aforyzm Mt 19, 28, uznany przez W. Kümela za dowodzący ${ }^{89}$, jest dla Kleina podejrzany już przez samo pojęcie odrodzenia - palingenesia; przekaz tradycji o wyborze Macieja wraz z leżącym u jego podstaw wyobrażeniem o Jedenastu nosi, jak sądzi, cechy drugorzędne ${ }^{90}$.

Z krytycznymi zarzutami Kleina w odniesieniu do dwu ostatnich argumentów nie można się również zgodzić. Najpierw co się tyczy logionu Mit 19, 28 par. należy zauważyć, że ogromna większość autorów protestanckich, a także i uczeni katoliccy, opowiadają się za jego autentycznością, co jednakże stanowi zarazem argument za istnieniem grupy Dwunastu w okresie ziemskiego życia Jezusa ${ }^{91}$. Poważni autorzy protestanccy uznają również autentyczność przekazu tradycji o wyborze Macieja, a to zakłada oczywiście znów ukonstytuowanie Dwunastu w wymienionym czasie. Zagadnienie to będzie rozpatrywane dalej, przy omawianiu najnowszej publikacji Rengstorfa.

Krytyczne swe uwagi pod adresem argumentacji za istnieniem Dwunastu w okresie ziemskiego życia Jezusa kończy Klein ogólnym wnioskiem: „Da się dowieść z prawdopodobieństwem graniczącym z pewnością, że Dwunastu jako instytucja nie należą do życia Jezusa" 92. Przeprowadzona wyżej analiza wywodów Kleina skłania jednak do zdania, iż wniosek jego jest nieuprawniony. Argumenty za historycznością Dwunastu w okresie ziemskiego życia Jezusa, poddawane przez Kleina krytyce, okazują się - nawet brane oddzielnie, a tym bardziej rozpatrywane

st G. Klein, dz. cyt., 36 n.

sy W. Kümmel, dz.cyt., 31 .

(19) G. Klein, dz. cyt., 36 .

91 Por. W. Kümmel, dz. cyt., 31; J. Dupont, Le logion de Douze Trônes (Mt 19. 28; Lc 22, 28-30), „Biblica”, Romae, 45 (1964) 385-390; B. Rigaux, art. cyt., 476 n. y: G. Klein, dz. cyt., 37. 
w powiązaniu ze sobą - mocniejsze niż wytaczane przeciwko nim zarzuty. By jednak twierdzenie to nie wydawało się gołosłowne, pożyteczną rzeczą będzie tutaj odwołać się do krytyki stanowiska Kleina podjętej w obozie protestanckim.

Doskonałą ocenę krytyczną poglądów Kleina i Schmithalsa na apostolat nowotestamentalny zawdzięczamy szwedzkiemu teologowi protestanckiemu, B. Gerhardssonowi. Ze względu na jej doniosłość dla całości naszego zagadnienia wypada tu przytoczyć ważniejsze jej momenty

Gerhardsson rozpoczyna swa krytykę wymienionych autorów od uwag natury ogólnej oraz od podania zastrzeżeń metodologicznych. Zauważa, że obydwu tych badaczy cechuje duży sceptycyzm w odniesieniu do badanych źródeł oraz w stosunku do poglądów innych uczonych. Sami jednak przyjmują bezkrytyczną postawę względem własnych hipotez i własnego tendencyjnego traktowania źródeł. Zdaniem Gerhardssona, zarówno u Kleina jak i Schmithalsa dostrzegamy metodyczny błąd, polegający na tym, że przy samej analizie i przy podstawowym toku rozumowania są oni skromni, uwzględniają różne niuanse, lecz następnie, przy wyciąganiu wniosków i związanej z nimi kolejnej argumentacji, są apodyktyczni. Obydwaj ci badacze ostrymi nożami dokonują sekcji prachrześcijańskich pism, lecz odnosi się wrażenie, że w ten sposób nie zo staje uchwycona przez nich ówczesna atmosfera, późnożydowskie, hellenistyczne i prakościelne środowisko. Prachrześcijańskie dokumenty, powiada Gerhardsson, należy przecież z reguły traktować jako bezpośrednie wyrazy życia młłodego Kościoła, żywej, religijnej i społecznej jed-ności, a nie tylko jako ksiegi napisane przez jakiegoś autora. Zwodniczym, jak sądzi szwedzki uczony, jest także wychodzenie przy interpretacji historycznych problemów od naciąganych, pojęciowych określeń. czego przykładem jest szczególnie Schmithals ${ }^{93}$.

Po tych ogólnych uwagach stawia Gerhardsson Kleinowi i Schmithalsowi bardziej konkretne zarzuty. Po pierwsze, że bardzo uproszczony jest ich pogląd na naturę związku, zachodzącego między warstwami tradycji dotyczącymi Jezusa i młodego Kościoła. Po wtóre, że bardzo nie realistyczny jest ich pogląd o związku prachrześcijaństwa z żydowską traáycją macierzystą ${ }^{94}$. Zarzuty te rozwija następnie Gerhardsson szcze-gólowo. Interesujący dla nas jest szczególnie zarzut pierwszy, gdyż dotyczy on $\mathrm{m}$. in. zagadnienia apostolatu.

Według Gerhardssona, jest rzeczą rozumną przyjąc, że Jezus z Nazaretu podczas swej działalności miał przynajmniej jakąś liczbę zwolenników. W związku z tym Gerhardsson stawia pytania: Jeśli Jezusowi udało się zdobyć zwolenników, to gdzie potem zniknęli? Jakże to nieznanych

93 B. Gerhardsson, art. cyt., 99 n.

94 Tamże, 100. 
Jezusowi dwunastu mężów mogło nagle doznać w Jerozolimie wizji Chrystusa i bez ogródek uważać się za prawnych współrządców mającego wkrótce powrócić Syna Człowieczego Jezusa Chrystusa? Jakże to ci Dwunastu mogli następnie zostać tak wcześnie i konsekwentnie narzuceni na dzieje Jezusa i jak mogli zostać Jego uczniami par excellence? I $\mathrm{w}$ jaki sposób można to pogodzić z naszymi wiadomościami o tworzeniu innych współczesnych grup żydowskich? Czyż nie jest po prostu możliwe, że - jak twierdzą chrześcijańskie źródła — zachodzi określony, organiczny związek między kręgiem wokół Jezusa z Nazaretu a sprawującym kierownictwo i znajdującym się w Jerozolimie po chrześcijańskiej Wielkanocy kręgiem w gminie Jezusa Chrystusa?

Dalej wskazuje Gerhardsson na to, że nie pierwszy Lukasz dokonał zakotwiczenia głównych uczniów Jezusa w Jego dziejach, wszysey bowiem synoptycy rozpoczynają opis publicznej działalności Jezusa od informacji, że otoczył się On uczniami. Szczególną uwagę zwraca Gerhardsson na tekst Mk 3, 13. 19. Interpretując go podkreśla najpierw, że Jezus epoiesen dōdeka, tj. ukonstytuowal Dwunastu. Opierając się na tym fakcie wyciąga Gerhardsson szereg wniosków. Zdaniem jego jest rzeczą najbardziej naturalną, że główni uczniowie Jezusa stali się po Jego odejściu centralnymi postaciami w ruchu wznieconym przez Niego i że kontynuowali dalej Jego dzieło. Najbardziej naturalne jest również, że oni otrzymali objawienie Chrystusa oraz że uważali się za prawnych przekazicieli i wykładaczy nauki Jezusa od momentu właściwej godziny narodzin Chrystusa ${ }^{95}$.

Przytoczore tutaj zarzuty i pytania Gerhardssona pod adresem Kleina i Schmithalsa świadczą, jak widać, że uczony szwedzki opowiedział się zdecydowanie za tezą o ukonstytuowaniu kolegium Dwunastu przez ziemskiego Jezusa oraz o ich dalszej działalności po Jego Zmartwychwstaniu. W dalszym ciągu swych wywodów autor ten zajmuje się bliżej zagadnieniem apostolatu chrześcijańskiego. Zauważa najpierw, że tezy Kleina i Schmithalsa o powstaniu tegoż apostolatu wzajemnie się sobie sprzeciwiają. Klein, jak powiada, nie wierzy w teze Schmithalsa o powstaniu kościelnego apostolatu, a Schmithals w tezę Kleina o wyłonieniu się idei apostolatu Dwunastu ${ }^{96}$. Żartobliwie dodaje, że czytelnikowi należy wybaczyć, jeśli nie będzie się czuł przekonanym prezz żadną z tych

95 Tamże, $101 \mathrm{nn}$.

96 Należy tu dodać pewne wyjaśnienie. Schmithals - jak wspomniano - przyjął tezę o powstaniu pojęcia chrześcijańskiego apostoła w Antiochii syryjskiej, Klein zaś za właściwego twórce idei dwunastu apostołów uznał Eukasza. Zajęcie wzajemnie krytycznych stanowisk wzgledem głoszonych przez siebie tez było u wymienionych autorów możliwe dlatego, że Klein zapoznał się najpierw z maszynopisem pracy Schmithalsa i dzięki temu mógł wykorzystać i ocenić jego poglądy, z kolei zaś Schmithals otrzymał wydrukowaną rozprawę Kleina już po napisaniu swej pracy i zajął $w$ odniesieniu do niej stanowisko w przypisach oraz w aneksie. 
tez. Powstanie chrześcijańskiego apostolatu jest jednak zdaniem Gerhardssona problemem, nad którym trzeba jeszcze pracować ${ }^{97}$. I temu zadaniu poświęca dalszą część- swej rozprawy. Nie na miejscu byłoby tu jej referowanie, gdyż zadaniem niniejszego artykułu nie jest przedstawianie koncepcji Gerhardssona. Dla ułatwienia czytelnikowi wyrobienia sobie poglądu na wartość radykalnej tezy Kleina i Schimithalsa będzie jednak rzeczą pożyteczną odnotować najważniejsze argumenty Gerhardssona za ustanowieniem apostolatu przez Jezusa Chrystusa.

Gerhardsson rozróżnia dwa typy chrześcijańskiego apostolatu. Pierwszy $\mathrm{z}$ nich to ograniczony czasowo apostolat $\mathrm{z}$ okresu ziemskiego życia Jezusa. O jego istnieniu wnioskuje przede wszystkim z tekstu $\mathrm{Mk}$ 3, 15 nn. Zdaniem jego ewangelista mówi tutaj o zamiarze Jezusa obliczonym na dłuższą metę: chce On ich wysłać, by głosili słowo i by mieli władzę nad duchami. Jeśli jednak do działalności samego Jezusa należało głoszenie słowa i wypędzanie demonów, to - pyta Gerhardsson dlaczego miałoby być nieprawdopodobne, że potrzebował On niekiedy swych głównych uczniów jako współpracowników i że dał im władzę, która - mutatis mudandis - przypomina władzę rabina udzielającego pełnomocnictwa swym uczniom, by czynili, co on czyni? ${ }^{98}$

Drugi etap chrześcijańskiego apostolatu stanowi, według Gerhardssona, właściwy i definitywny apostolat, ustanowiony przez Chrystusa Zmartwychwstałego. Argumenty za jego istnieniem czerpie uczony szwedzki z listów Pawłowych. Z listów tych, jak zauważa, dowiadujemy się, że w prachrześcijaństwie mamy do czynienia ze szczególnym typem posłańców, jakimi są apostołowie Chrystusa. Kategoria ta, zdaniem Gerhardssona, nie jest wszakże tworem Pawła. W Gal 1, 17 mówi on bowiem, że po swym nawróceniu nie udał się do tych, którzy przed nim byli apostołami. Włącza się więc do istniejącej już kategorii. Według Gerhardssona, jest czymś w najwyższym stopniu wyszukanym, jeśli jak to czyni Schmithals - twierdzi się, że kategorię tę przejął Paweł z hellenistycznej gminy $w$ Syrii, która ze swej strony otrzymała ja w spuściźnie od gnostycyzmu. Teza taka jest nie do pogodzenia ze świadectwem Pawła, wyrażonym w cytowan̉ym wyżej tekście listu do Galatów, który przecież jest starym i pewnym źródłem. Od samego Pawła dowiadujemy się tedy, że już przed jego nawróceniem istnieli chrześcijańscy apostołowie i że przynajmniej ci spośród nich, którzy sprawowali rolę kierowniczą, byli obecni w Jerozolimie. Poza tym jest w najwyższym stopniu nieprawdopodobne, by w tym punkcie Paweł był źle poinformowany. Mamy tu do czynienia z tak ważnym świadectwem, że nie. 
wolno nam go przy pomocy jakiejś interpretacji odrzucić, by przez to zrobić miejsce dla pustej hipotezy ${ }^{99}$.

Gerhardsson stawia w końcu pytanie, czy Dwunastu byli również apostołami w definitywnym, właściwym tego słowa znaczeniu. Pytanie to zbiega się według niego $\mathrm{z}$ problemem, czy w prachrześcijaństwie wierzono, że otrzymali oni władzę apostolską od samego Chrystusa Zmartwychwstałego. Twierdząca odpowiedź, jak sądzi, nie podlega tu żadnej wątpliwości. Gerhardsson usprawiedliwia się, że nie może przytoczyć całego materiału z Nowego Testamentu, dającego wyraz przekonaniu prachrześcijaństwa o otrzymaniu przez Dwunastu władzy apostolskiej od samego Chrystusa. Podkreśla przy tym, że ich łączność z Jezusem była rzeczywista, bo nie ograniczała się jedynie do spotkania ze Zmartwychwstałym, na skutek czego w Prakościele nie zmieniono ich nazwy „Dwunastu", mimo iż wiedziano, że są apostołami. Dopiero po upływie około dwu dziesiątków lat, jak przypuszcza Gerhardsson, gdy Dwunastu opuścili Jerozolimę, by sprawować swój apostolat także i w diasporze, stało się sensowniejsze określać ich nazwą apostołów, gdyż jako Dwunastu, czyli jako kolegium, nie stanowili już więcej jedności ${ }^{100}$.

\section{WYBÓR ŚW. MACIEJA NA APOSTOEA}

Do zagadnienia historyczności kolegium Dwunastu przed Wielkanoca i zakotwiczenia ich apostolatu w ziemskim życiu Jezusa powrócił Rengstorf w swej pracy poświęconej problemowi wyboru Macieja ${ }^{101}$, opublikowanej już po II wojnie światowej. Roztrząsając wymieniony problem zajął Rengstorf stanowisko krytyczne wobec poglądów na ten temat E. Haenchena, wyłożonych w jego komentarzu do Dziejów Apostolskich. Wypada tutaj zapoznać się z wywodami obydwu tych autorów.

Chcąc zrozumieć stanowisko Haenchena w sprawie wyboru Macieja trzeba najpierw uprzytomnić sobie, jak autor ten ocenia księgę Dziejów Apostolskich, w szczególności jak pojmuje istotne jej cechy i w czym doszukuje się bodźców jej powstania.

Haenchen zajmuje krytyczne stanowisko zarówno w odniesieniu do kościelnej tradycji dotyczącej Dziejów Apostolskich, jak i względem bar-

99 Tamże, 188. 121.

100 Tamże, 129.

101 Problemowi temu poświęciło w ostatnich czasach, oprócz Rengstorfa, swe rozprawy kilku autorów. Por. J. Renies, L'élection de Mathias (Act I, 15-26): authenticité de récit, „Revue biblique", Paris, 53 (1948) 43-55; P. Gaechter. Die Wahl des Matthias (Apg 1, 15-26), ,Zeitschrift für Katholische Theologie”, Wien, 71 (1949) 318-346; C. Masson, La reconstitution du collège des Douze d'après Actes 1, 15-26, „Revue de Théologie et de Philosophie”, 3, ser., 5 (1955) 193-201; P. Menoud, Les additions au groupe des douze apôtre d'après le livre des Actes, ,Revue d'histoire et de philosophie religieuses", 37 (1957) 71-80; E. Haenchen. Die Apostelgeschichte. Meyers Kommentar, III, Göttingen ${ }^{6} 1968$, 122-130. 
dziej konserwatywnej interpretacji tej księgi. Głównym przedmiotem jego zainteresowań jest problematyka właściwa metodzie Formgeschichte, tj. przede wszystkim badanie odrębnych jednostek wchodzących w skład księgi oraz jej literacka i teologiczna kompozycja ${ }^{102}$.

Według Haenchena, istotny sens opowiadania o wyborze Macieja wiąże się z zamiarem, jaki przyświecał Eukaszowi przy pisaniu Dziejów Apostolskich. Zamiar ten wynika mianowicie z jego koncepcji teologicznej. Kierując się nim łukasz nie chciał w swej księdze donosić tylko o tym, jak toczyły się po sobie wydarzenia. Chciał raczej Kościołowi ówczesnemu wyświadczyć szczególną teologiczno-duszpasterską przysługę, której tenże w owych czasach bardzo potrzebował. Kościół znajdował się bowiem wtedy w trudnej i krytycznej sytuacji. Chrześcijanie byli przekonani, że wkrótce nastąpi powtórne przyjście Jezusa-Mesjasza. Oczekiwania ich nie spełniły się jednak. Gdy Łukasz pisał Dzieje Apostolskie, Paweł został ścięty, brat Pański Jakub poniósł śmierć męczeńską, chrze-ścijanie byli paleni żywcem w ogrodach Nerona, a święte miasto Jeruzalem zostało zburzone. Dzieje świata toczyły się jednak dalej. Chrześcijanie uświadomili sobie, że byli w błędzie oczekując bliskiego końca świata ${ }^{103}$. Także i Łukasz nie opowiedział się za oczekiwaniem rychłego przyjścia Chrystusa, gdyż podzielanie takiego poglądu wkraczałoby, jego zdaniem, w zakres wyłącznej wiedzy Bożej. Uważał, że chrześcijanie mają się liczyć z dalszym trwaniem świata. Związane jest z tym, jak sądzi Haenchen, pytanie: w jaki sposób chrześcijaństwo, które uważało się za wielkie prowizorium, odniesie się do tej nieoczekiwanej sytuacji? Nawiązując do idei rozwiniętych przez $\mathrm{H}$. Conzelmanna w dziele Die Mitte der Zeit 104 utrzymuje Haenchen, że Eukasz rozróżniał trzy epoki. Pierwszą z nich była epoka Prawa i Proroków, która skończyła się wraz z Janem Chrzcicielem. Drugą, zwaną „środkiem czasów" - Mitte der Zeit - wyznaczało ziemskie życie Jezusa. Trzecia wreszcie rozpoczęła sie wraz $z$ Wniebowstąpieniem Jezusa. Epokę tę nazywa Haenchen czasami Kościoła lub dziejami Kościoła ${ }^{105}$. Właśnie w Dziejach Apostolskich stara się Łukasz, zdaniem Haenchena, udzielić odpowiedzi na postawione pytania, dając wraz z przedstawieniem dalszego ciągu sprawy pewien zarys teologii dziejów Kościoła. W tym celu przepracowuje on posiadany materiał ujmując go w krótkie, dramatyczne sceny, tak by czytelnika. swego pouczyć i dopomóc mu w sposób właściwy w nowej sytuacji się zachować ${ }^{106}$.

102 E. Haenchen, dz. cyt., 72.

103 Tamże, 84 n.; por. H. Rengstorf, Die Zuwahl des Matthias, 36 n.

104 H. Conzelmann, Die Mitte der Zeit. Studien zur Theologie des Lukas, Tübingen 1960 .

105 E. Haenchen, dz. cyt., 86.

106 Tamże, 93; por. H. Rengstorf, art. cyt., 37. 
Pierwszym przykładem, przy pomocy którego Haenchen ilustruje sto-sowanie przez autora Dziejów Apolstolskich takiej metody, jest wybór Macieja. Łukasz, powiada Haenchen, mógłby na początku swych Dziejów Apostolskich powiedzieć swym czytelnikom: ponieważ krąg Dwunastu stał się niepełny na skutek zdrady Judasza, musieli oni wybrać za niego innego apostoła, był nim Maciej. Takie zdanie niewiele by jednak, jak sądzi Haenchen, mówiło czytelnikom, dlatego Łukasz postąpił inaczej: roztoczył przed ich oczyma żywą scenę, dla której skonstruował przemówienie Piotra ${ }^{107}$. Nie znaczy to jednak, że sam Łukasz wszystko w tym opisie wynalazł. Haenchen przyznaje, że nie Łukasz pierwszy opowiadä o karze Bożej na Judasza. Widoczne jest tu oddziaływanie palestyńskiej tradycji. Także i interpretację psalmu przejął on od chrześcijaństwa palestyńskiego. Wreszcie informacja, że Maciej a nie Barsabas stał się przez losowanie apostołem, sprowadza się również do tradycji. Niemniej podkreśla Haenchen, że z przekazu tradycji nie uczynił Eukasz suchego, historycznego sprawozdania, lecz stworzył z niego żywą scenę. Jej centralnym punktem jest Piotr, mówiący do gminy o śmierci Judasza i o wyborze, którego chee Bóg. Zdaniem Haenchena, Łukasz wykorzystał tę okoliczność, aby podkreślić przez to w pośredni sposób rolę dwunastu apostołów. Polega ona mianowicie na tym, że są oni przede wszystkim świadkami Zmartwychwstania Jezusa. Jest to dla Łukasza szczególnie ważne, gdyż główny punkt ciężkości jego teologii spoczywa na Zmartwychwstaniu. Po wtóre, rola Dwunastu polega również na tym, że są oni świadkami życia ziemskiego Jezusa. Przez to są oni poręczycielami ewangelicznej tradycji jako hyperetai tou logou ${ }^{108}$.

Do innych wniosków w sprawie wyboru Macieja dochodzi we wzmiankowanym wyżej studium H. Rengstorf. Wyraża on najpierw aprobatę dla zamierzeń Haenchena, usiłującego wczuć się w teologiczną koncepcję autora Dziejów Apostolskich. Zdaniem Rengstorfa, zasługuje bowiem to na uznanie, że egzegeza nie ogranicza się jedynie do badania filologicznych i historycznych problemów dotyczących danego tekstu, lecz troszczy się również o ukazanie jego teologicznego znaczenia. Nie zadowala wszakże Rengstorfa odpowiedź, jaką dał Haenchen na postawione przez siebie pytanie. Rengstorf uważa, że z odpowiedzią tą nie można się zgodzić dlatego, ponieważ nie bierze ona pod uwagę osobliwej właściwości przysługującej ustępowi o wyborze Macieja, a polegającej na odizolowaniu tegoiz ustępu w całości księgi Dziejów Apostolskich. Mianowicie zdarzenie, którym się ów ustęp zajmuje, zdaje się być bez większego znaczenia dla dalszego ciągu wydarzeń opisywanych przez Eukasza. Uwidacznia się to w fakcie, że Maciej nie zostaje później ani raz wymieniony. Także i Dwu-

107 E. Haenchen, dz. cyt., 93 n.

108 Tamże, 128 n. 
nastu odgrywają w dalszym ciągu księgi bardzo znikomą rolę. Okoliczność ta stanowi zdaniem Rengstorfa zasadniczy argument przeciwko tezie Haenchena, według której, jak widzieliśmy, w intencji Łukasza opowiadanie o wyborze Macieja miało przede wszystkim podkreślać rolę i znaczenie dwunastu apostołów ${ }^{109}$.

Odrzucenie tezy Haenchena skłania Rengstorfa do podjęcia próby dania innej odpowiedzi na pytanie, czym się kierował Łukasz, umieszczając na początku Księgi Dziejów Apostolskich przekaz tradycji o wyborze $\mathrm{Ma}$ cieja. W dociekaniach, jakie zadaniu temu Rengstorf poświęca, wyróżnić można dwa główne etapy. Etap pierwszy stanowi rozważenie wstępnych problemów analizy tekstu o wyborze Macieja. Na etapie tym Rengstorf stara się przede wszystkim odpowiedzieć na pytanie, co tłumaczyło sam wybór Macieja. Dochodzi tutaj do interesujących wniosków. Sądzi, że jedyna droga do wytłumaczenia wymienionego wyboru musi wyjść od takiego rozumienia powstania i roli grupy Dwunastu, jakie dane jest w tradycji synoptycznej. Tradycja ta zgodna jest w twierdzeniu, że krąg ten został ustanowiony przez samego Jezusa. Trzy relacje, jakie o tym wydarzeniu posiadamy, tj. Mk 3, 13 nn.; Mt 10, 1 nn.; 6, 12 nn., nie są wprawdzie zgodne we wszystkich szczegółach, jednakowoż zawierają trzy wspólne momenty, których historyczności nie można zanegować. Po pierwsze, Jezus z własnej inicjatywy wybrał z szerszego kręgu uczniów krąg węższy. Po drugie, liczbę należących do tego kręgu ograniczył do dwunastu. Po trzecie wreszcie, wybranych w ten sposób przeznaczył do tego, by Jego dzieło - tak jak je rozumiał - wypełniali z Nim i według Jego wskazówek; dlatego udzielił im wymaganej do tego celu władzy i w sposób zgodny z żydowską instytucją prawną Jego czasów uczynił ich swymi ,apostołami". Niezależnie od tego, w jaki sposób po śmierc: i zmartwychwstaniu Jezusa rozwijało się potem w gminie chrześcijańskiej i poza nią pojęcie apostoła i jakie wpływy determinowały jej rozwój, bez wymienionych trzech momentów apostolat najstarszego chrześcijaństwa, o ile ma być apostolatem Chrystusa, byłby jako historyczne zjawisko niezrozumiały, a obraz prachrześcijaństwa byłby jeszcze bardziej zagadkowy ${ }^{110}$. Wymienione dane tradycji stanowią wszakże, zdaniem Rengstorfa, jedynie założenie opisu wyboru Macieja, ale go nie uzasadniają. Uzasadnienie opisu, czyli jego cel, musi leżeć gdzie ind ej. Wykryciu tego celu służy drugi etap dociekań Rengstorfa stanowiący właściwą analizę odnośnego tekstu. Prowadzi ona uczonego do następującego rezultatu.

Motywem, dla którego Łukasz przejął przekaz chrześcijańskiej tradycji o wyborze Macieja i umieścił go na początku księgi Dziejów Apo-

109 H. Rengstorf, art. cyt., $39 \mathrm{n}$.

110 Tamże, $45 \mathrm{n}$. 
stolskich, było to, że był on mu nieodzowny $z$ teologicznych względów. Tradycja ta świadczy bowiem, że niezmieniona pozostaje wola Boża co do ewangelizacji Izraela także i po odrzuceniu przez ten naród Jezusa, i nawet wtedy, gdy wydawałoby się, że krąg Dwunastu, zewnętrzny znak roszczeń Jezusa względem Izraela, został wraz z Jego śmiercią zalamany ${ }^{111}$.

Porównanie wniosków, jakie w sprawie wyboru Macieja wyprowadzili Haenchen i Rengstorf, sprawia wrażenie pewnego niedosytu i nasuwa szereg nowych problemów. Obydwaj ci autorzy, jak widzieliśmy, postawili sobie jedno i to samo zasadnicze pytanie: czym kierował sie Łukasz umieszczając w Dziejach Apostolskich opis wyboru Macieja? Obydwaj utrzymują przy tym również, że kierując się takim a nie innym motywem chciał Łukasz przez wymieniony opis pouczyć swych czytelników o pewnej prawdzie. Jest jednak rzeczą osobliwą, że uczeni ci dochodzą na drodze swych dociekań do różnych odpowiedzi, przy czym jeden $z$ nich wyraźnie neguje i odrzuca odpowiedź drugiego. Wobec takiego stanu rzeczy nie można oprzeć się nasuwającym się wątpliwościom. Ro.* dzą się pytania: czyżby czytelnicy dzieła Łukaszowego - a byli to przypuszczalnie po większej części ludzie bez głębszego przygotowania teologicznego - potrafili łatwiej odczytać ów motyw opisu wyboru Macieja i wypływającą $z$ niego naukę niż wytrawni teologowie, którzy mimo żmudnych dociekań i stosowania całego aparatu naukowego dzisiejszej wiedzy egzegetyczno-teologicznej nie są w stanie - przynajmniej jak to widzieliśmy na przytoczonych przykładach — ustalić w jednoznaczny sposób, co właściwie autor Dziejów Apostolskich chciał swym czytelnikom w odnośnym ustępie powiedzieć? Jeśli nie, to czemu Łukasz wyraził ową naukę w sposób tak zamaskowany? Czy nie potrafił prościej i jaśniej powiedzieć, o co mu właściwie chodzi? Te i inne pytania krytyczne, jakie nasuwają się pod adresem wniosków wymienionych badaczy, zmuszają do potraktowania rezultatów ich dociekań z dużą rezerwą. Dlatego też prowadzą nas do wyrobienia sobie nieco innego zdania na temat sensu Eukaszowego opisu wyboru Macieja. Wydaje się, że autor Dziejów Apostolskich chciał w tym wypadku przede wszystkim poinformowaé swych czytelników o owym wydarzeniu, jakim był wybór Macieja. W taki to sposób odczytuje chyba wymieniony ustęp każdy prosty, nieuczony czytelnik. Że niezależnie od tego chciał Łukasz w wymienionym miejscu jeszcze o czymś swych czytelników pouczyć, to inna sprawa, nie ulegająca zresztą dzisiaj wątpliwości w oparciu o naukowe badania księgi Dziejów Apostolskich. Temu celowi ma niewątpliwie służyć przemówienie Piotra. Na podstawie stanu obecnych badań trzeba przyznać, że przemówienie to zostało faktycznie skomponowane przez Łukasza. Nie zna-

111 Tamże, 60. 
czy to jednak, że zostało ono całkowicie przez niego zmyślone. Raczej zaczerpnął on z tradycji wiadomość o fakcie wygłoszenia takiego przemówienia przez Piotra, a prawdopodobnie przejął z niej także informacje co do głównych tematów przez niego w przemówieniu poruszonych i dopiero w oparciu o tego rodzaju materiał stworzył według własnego stylu resztę. Jeśli tak rzecz się miała, wraca jednak w dalszym ciągu owo niełatwe pytanie: o czym chciał Łukasz swych czytelników w opisie wyboru Macieja pouczyć? Wydaje się, że odpowiedzi na to pytanie dane przez Haenchena i Rengstorfa nie wykluczają się wzajemnie, lecz że obydwie mogą być w pewnej mierze prawdziwe. Wszakże bardziej zadowalająca zdaje się być odpowiedź pierwszego $\mathrm{z}$ wymienionych autorów. Podkreślenie znaczenia i roli dwunastu apostołów jest bowiem wyraźnie zawarte w przemówieniu Piotra, dlatego jest chyba rzeczą nie ulegającą wątpliwości, że takie rozumienie owego przemówienia nasuwać się będzie każdemu, zwłaszcza zaś prostemu czytelnikowi. Nie stoi temu na przeszkodzie zauważony przez Rengstorfa fakt, że opis wyboru Macieja stanowi ustęp odizolowany w całości księgi, ani też stwierdzenie, że Łukasz był uniwersalistą. Rengstorf nie liczy się bowiem z tym, że koncepcja apostolatu ulegała w pierwotnym chrześcijaństwie, a także, być może, i u Łukasza, rozwojowi. Rozwój ten Dzieje Apostolskie w pewnej mierze odzwierciedlają, podobnie jak np. przedstawiają nam one rozwój, a nawet zmianę poglądów Piotra co do potrzeby prowadzenia misji wśród pogan. Nie jest tedy wykluczone, że opis wyboru Macieja, podkreślając znaczenie i rolę Dwunastu dla narodu izraelskiego, odzwierciedla właśnie pierwszy etap rozwoju koncepcji apostolatu. Po tym etapie, w związku ze zmianą stanowiska Piotra co do prowadzenia misji wśród pogan, a zwłaszcza z powołaniem na apostoła Pawła i jego działalnością, nastąpiłby dopiero etap drugi.

Prawda, o której według tezy Rengstorfa Eukasz chce pouczyć swych czytelników, tj. prawda o niezmienionych nawet przez śmierć Jezusa planach Bożych względem Izraela, zawiera się - jak się wydaje - również w przemówieniu Piotra, ale nie jest ona w nim zawarta tak wyraźnie, jak podkreślenie znaczenia roli Dwunastu. Można by powiedzieć, że przemówienie to wymienioną prawdę implikuje, tak że uświadomienie jej sobie suponuje u czytelnika głębszy namysł oraz jakieś przygotowanie teologiczne.

\section{NATURA APOSTOLATU NOWOTESTAMENTALNEGO}

Rozważając problem historyczności kolegium Dwunastu w okresie ziemskiego życia Jezusa odbiegliśmy od zasadniczego toku wywodów, referujących i oceniających poglądy Rengstorfa, wyłożone w głównym jego 
studium poświęconym zagadnieniu apostolatu, tj. w artykule apostolos. Obecnie wypada zając się dalszym ciągiem poglądów tego autora.

W związku z problemem ustanowienia przez ziemskiego Jezusa apostolatu Dwunastu wypowiada Rengstorf także uwagi co do natury tegoż apostolatu. Słowa Jezusa zawarte w Mt 10, 40 nn.; Mk 9, 41; Ek 10, 16 nie tylko - jak sądzi Rengstorf - poświadczają apostolat, lecz zarazem ukazują go w jego powiązaniu z ideą posługi i pokory i przez to oczy:szczają go z roszczeń prawnych, które charakterystyczne są dla Pawłowej koncepcji apostolatu. Tym samym jednak wykluczone jest, by Jezus podejmował jakikolwiek wysiłek zmierzający do utworzenia uformowanego prawnie urzędu gminy. W odniesieniu do apostolatu ukonstytuowanego przez ziemskiego Jezusa należy w związku z tym raczej unikać słowa ,urząd", a zamiast tego posługiwać się zwrotem ,mandat" - Auftrag - i to w sensie przestrzennie i czasowo ograniczonego oraz rzeczowo a nie osobowo uwarunkowanego upelnomocnienia ${ }^{112}$.

W toku rzeczowych wywodów Rengstorfa napotykamy tutaj po raz pierwszy na wypowiedzi, które w tym wypadku zdają się być podyktowane jego subiektywnym aprioryzmem. Pociaga to za sobą uproszczenie sprawy i wyciąganie nieuprawnionych wniosków. Z tego, co wyżej zostało powiedziane przez Rengstorfa, wynikałoby, że koncepcja apostolatu, jakə, miał Paweł, nie była zgodna z zamierzeniami Jezusa. Wniosek taki stawia jednak pod znakiem zapytania autentyczność spotkania Pawła ze Zmartwychwstałym i prawdziwość jego objawień. Nasuwa się bowiem od razu pytanie: jak to mogło się stać, że Paweł, któremu ukazał się Zmartwychwstały i powierzył mu misję apostolską, w sposób tak niezgodny z intencjami swego Pana pojął apostolat? Można przypuścić, że Rengstorf, starający się z tak niesłychaną troskliwością o odtworzenie rzeczywistəj nauki Nowego Testamentu o apostolacie, nie zgodziłby się z twierdzeniami, które w tak radykalny sposób kwestionują autentyczność Pawłowego powołania. A jednak twierdzenia te wynikają z wymienionego wyżej założenia Rengstorfa. Wynikałoby tedy stąd, że założenie to nie jest słuszne, a wszelkie wezwania Jezusa, zachęcającego swych apostołów do pokory i służebnej postawy, nie wykluczają bynajmniej udzielenia im autorytatywnej władzy urzędowej. Że nie jest to subiektywna interpretacja katolicka świadczy o tym choćby tylko dorobek protestanckich autorów bedących przedstawicielami tzw. antykrytyki, którzy przecież na pewno w swych badaniach nie kierowali się zalożeniami katolickimi, a jednak w oparciu o analizę źródeł doszli do wniosku o istnieniu autorytatywnego urzędu w pragminie opartego o postanowienia Jezusa ${ }^{113}$. Rengstorfowi

112 I (ThWNT) 427.

113 Należy tu wymienić przede wszystkim autorów: K. Holl, Der Kirchenbegriff des Paulus in seinem Verhältnis zu dem der Urgemeinde, w: ,Sitzungsberichte der 
można przyznać rację tylko o tyle, że wysiłki Jezusa nie zmierzały być może wyraźnie do utworzenia prawnie ukonstytuowanego urzędu w pragminie, lecz nie sprzeciwia się temu fakt, iż z apostolatu ukonstytuowa-nego przez Jezusa, noszącego - jak zauważa sam Rengstorf - trwały charakter, rozwinął się prawnie, tj. zgodnie z wolą Jezusa, taki urzą.

Trudniejsza od problemu autoryzacji apostolów jest, zdaniem Rengstorfa, odpowiedź na pytanie, czy w kręgu uczniów Jezusa istniała już nazwa apostoła. Szczegółowa analiza odnośnych tekstów ewangelijnych prowadzi jednakże Rengstorfa do wniosku, że trudno byłoby wątpić, iż zwrot apostolos sięga do Jezusa, oczywiście nie w greckiej formie, lecz w jego aramejskim oủpowiedniku šeliach 114 .

Drugi etap powstania apostolatu związany jest według Rengstorfa. jak wspomniano, z Jezusem Zmartwychwstałym. Autor ten uważa, że dziełem Zmartwychwstałego było to, iż z rozproszonego kręgu uczniów powstała pełna nadziei i chętna do pracy gmina. Dziełem Zmartwychwstałego było także odnowienie mandatu względem uczniów w ostatecznym akcie ustanowienia ich apostołami ${ }^{115}$. Innymi slowy przez Zmartwychwstałego został apostolat odnowiony względnie ostatecznie ukonstytuowany ${ }^{116}$.

Z treści wywodów Rengstorfa wynika, że udzielenie mandatu przez Zmartwychwstałego uznaje on za czynnik ostatecznie decydujacy dlat powstania apostolatu. Wskazuje bowiem na to, że apostołowie byli świadkami Zmartwychwstania, lecz że nie wszyscy świadkowie tego wydarzenia byli apostołami. W związku z tym uważa, że obok spotkania ze Zmartwychwstałym jedyną podstawą apostolatu zdaje się być otrzymanie od Niego osobistego mandatu. Podkreśla przy tym, iż na mocy owego mandatu ci, którzy podczas ziemskiego życia Jezusa należeli do Jego najbliższego otoczenia, stali się Jego namiestnikami w tym sensie, że weszli na Jego miejsce, przez co otrzymali autorytatywne stanowisko przede wszystkim w obrębie gromady chrześcijan ${ }^{117}$.

Do drugorzędnych przymiotów apostolatu zalicza Rengstorf skierowa-nie apostołów do działalności misyjnej. Sądzi, że przez zmienioną sytuację Dwunastu stali się misjonarzami. Chociaż o losie prawie wszystkich apostołów po Zielonych Swiętach nic nie wiemy, to jednak Mt 28, 19 n. opisuje nam chyba wystarczająco jasno, na czym on polegał. Powstający Kościół - jak wywodzi Rengstorf — byłby chyba tych słów w Ewangeliach nie ścierpiał, gdyby nie odpowiadały one stanowi rzeczywistemu ${ }^{118}$.

Preussischen Akademie der Wissenschaften zu Berlin", Phil.-hist. Klasse, Berlin 1921, 932; A. Schlatter, Die Theologie der Apostel, Stuttgart 21922, 503. 507. 533. 114 I (ThWNT) $427 \mathrm{nn}$.

115 Tamże, 431.

116 Tamże, 435.

117 Tamże, $431 \mathrm{n}$.

118 Tamże, 432. 
Według Rengstorfa, apostolat odnowiony i ostatecznie ukonstytuowany przez Zmartwychwstałego nosi trwały charakter. Ustanowił On bowiem swych przedstawicieli na cały okres czasu, jaki przebiega między Wielkanocą, a Jego powtórnym przyjściem. Ustanowił ich jednak jednorazowo, czego konsekwencją jest, że apostolat był związany $\mathrm{z}$ pierwszą generacją chrześcijan i nie stał się urzędem kościelnym ${ }^{119}$.

Przedłożone tutaj wypowiedzi Rengstorfa robią wrażenie zdań sprzecznych. Nasuwa się bowiem pytanie, w jakim znaczeniu można mówić, że apostolat ukonstytuowany przez Zmartwychwstalego nosi trwały charakter ze względu na to, że ustanowił on swych przedstawicieli na cały okres czasu przebiegający między Wielkanocą a Jego powtórnym przyjściem, jeśli równocześnie utrzymuje się, że apostolat został ustanowiony jako jednorazowy i że w konsekwencji tego jest on związany z pierwszą generacją chrześcijan. Rengstorf nie wyjaśnił niestety, co chciał przez to powiedzieć ani z jakich powodów wymienionej sprzeczności, jak można przypuszczać, nie dostrzegał ${ }^{120}$.

Uznanie udzielenia mandatu przez Zmartwychwstałego za czynnik konstytuujący ostatecznie apostolat nasuwa Rengstorfowi pewne problemy. Związane są one $\mathrm{w}$ szczególności $\mathrm{z}$ opisem wydelegowania przez gminę antiocheńską Pawła i Barnaby na misję oraz wyboru Macieja na apostoła. Obydwa te fakty sugerują bowiem myśl, że udzielenie mandatu przez Zmartwychwstałego nie było konieczne do powstania apostolatu. Trudności te usiłuje Rengstorf w oryginalny sposób rozwiązać. Co się tyczy pierwszego problemu podkreśla najpierw, że w Antiochii zostali przeznaczeni na misję właśnie Paweł i Barnaba, a nie kto inny, z których pierwszy na pewno, drugi zaś prawdopodobnie widział Zmartwychwstałego. Także i akt gminy, jak zauważa Rengstorf, wyrażony został nie przy pomocy czasownika apostellein, lecz aforizein (= wyłączyć, odłączyć), a inicjatywa tego aktu została przeniesiona na Ducha Świętego, tak że gmina miała dać tylko zewnętrzną autoryzację. W związku z tym Rengstorf sądzi, że da się zupełnie dobrze wyobrazić, iż obydwaj ci mężowie już od dawna posiadali apostolską moc — eksousia -lecz nie została ona jeszcze wprowadzona w czyn ${ }^{121}$.

Stanowisko Rengstorfa w tej sprawie wydaje się być słuszne. Wypada tu nadmienić, że niektórzy autorzy katoliccy proponują tutaj inne rozwiązania. Tak np. P. Gaechter sądzi, że przez zjawienie Zmartwychwstałego Paweł otrzymał jedynie powołanie na apostoła, natomiast for'malne posłannictwo i wprowadzenie na urząd apostolski zawdzięcza On

119 Tamże, 433.

120 Por. E. Kredel, Der Apostelbegriff in der neueren Exegese, ,Zeitschrift für Katolische Theologie", 78 (1956) 288.

121 I (ThWNT) 437. 
Dwunastu, o czym ma świadczyć tekst Gal 2, 1-10 122. Podobne stanowisko zajmuje E. Kredel ${ }^{123}$. Tezę Gaechtera można uznać jedynie za prawdopodobną hipotezę. Nie jest ona jednak zbyt przekonywująca i pociąga za sobą szereg trudności, w szczególności przemawiają przeciwko niej wszystkie teksty, w których Paweł podkreśla, że jest apostołem Jezusa Chrystusa (Gal 1, 1;1 i 2 Kor 1, 1) i że otrzymał swój apostolat przez Jezusa Chrystusa $(\mathrm{Rz} 1,5)$. Z tezą Gaechtera nie zgodzą się uczeni protestanccy. J. Roloff uważa np., że interpretacja, jaką daje Gaechter, jest możliwa jedynie przy pogwałceniu świadectw Pawłowych ${ }^{124}$. Bardziej słuszne wydaje się tedy stanowisko katolickiego autora K. Schelklego, który w zgodności z autorami protestanckimi utrzymuje, że Paweł otrzymał swe posłannictwo od wywyższonego Chrystusa (Dz 9, 27; Gal 1, 15 n.) oraz że według 1 Kor 15, 5 n. nie zjawienie Zmartwychwstałego czyni kogoś apostołem, lecz dopiero udzielenie posłannictwa ${ }^{125}$.

Poważniejszą trudność związaną z zagadnieniem podstaw apostolätu stanowi wybór na apostoła Macieja. Rengstorf zakłada milcząco, że nie jesteśmy niczym upoważnieni do stwierdzenia, iż w przypadku Macieja nastąpiło również spełnienie podstawowego warunku apostolatu, tj. udzielenie Maciejowi apostolskiego mandatu przez Zmartwychwstałego. Skłania to Rengstorfa do wniosku, że warunku tego nie uważano w pragminie za wyłączną i jedyną podstawę apostolatu. Decydującą rolę, jak sądzi, odegrał natomiast w wypadku wyboru Macieja inny moment, mianowicie przymiot bycia świadkiem (Augenzeugenschaft). Znaczy to, że pragmina nie uważała w każdym razie posłania przez Zmartwychwstałego za czynnik radykalnie nowy. Aczkolwiek ze względu na brak w tej sprawie wiadomości w źródłach nie możemy uzyskać zupełnie jasnego obrazu interesującej nas rzeczywistości, to jednak najbliżej niej będziemy, jeśli uznamy, że nowe posłanie nie było dla gminy niczym innym, jak tylko powtórzeniem lub kontynuacją posłania danego za czasów ziemskiego życia Jezusa ${ }^{126}$.

Powyższe wywody Rengstorfa odnośnie koncepcji apostolatu przyjmowanej w pragminie należy uzupełnić jego wypowiedziami na ten temat w rozprawie poświęconej wyborowi Macieja. Utrzymuje w niej, iż da się wykazać, że relacja o wyborze Macieja zakłada swoistą, anachroniczną koncepcję apostolatu w powielkanocnej tradycji. Nie wolno tej koncepcji uważać za przedwielkanocną, ale jest ona naiwna, gdyż nie bierze pod uwage, jak fundamentalne znaczenie ma wydarzenie wiel-

\footnotetext{
122 P. Gaechter, Petrus und seine Zeit, Insbruck 1958, $422 \mathrm{nn}$.

123 E. Kredel, art. cyt., 303.

124 J. Roloff, dz. cyt., 30.

125 K. Schelkle, Apostel. I - Biblisch, w: LThK, 1 ('21957) 735.

126 I (ThWNT) 437
} 
kanocne zarówno dla aktualnego działania Chrystusa, jak i dla istoty charakteru odnowionego apostolatu ${ }^{127}$.

Wątpliwości wysunięte tutaj przez Rengstorfa wskazują na to, że pojęcie apostolatu nie jest $\mathrm{w}$ Nowym Testamencie zupełnie jednoznaczne. Prowadzi to do wniosku, że i sama ta instytucja nie jest tworem jednorodnym. Czy jednak w związku z tym zachodzi konieczność uznania koncepcji apostolatu, wyrażonej przez Łukasza w opisie wyboru Macieja, za anachroniczną i naiwną? Konieczność taka, jak się zdaje, nie zachodzi. Raczej należałoby przyjąć, że nie jest to koncepcja anachroniczna, lecz niepełna. Wyraża ona jeden rys apostolatu, przysługującego wyłącznie Dwunastu, mianowicie to, że byli oni świadkami ziemskiego życia Jezusa. Rengstorf nie wziął pod uwagę, że taka niepełna koncepcja apostolatu nie stoi $\mathrm{w}$ sprzeczności $z$ koncepcja apostolatu $\mathrm{w}$ pełnym tego słowa znaczeniu, tj. apostolatu ukonstytuowanego przez mandat Zmartwychwstałego.

\section{APOSTOLAT ŚW. PAWEA}

Trudności związane z apostolatem Macieja kierują uwagę Rengstorfa na apostolat Pawła. Rengstorf zauważa najpierw, że powiązanie apostolatu $\mathrm{z}$ osobistym udziałem $\mathrm{w}$ dziejach Jezusa dotyczyło $\mathrm{w}$ dwojaki sposób Pawła. Po pierwsze mianowicie, zanegowanie słuszności jego roszczeń apostolskich, wyrażającyç się $\mathrm{w}$ postawieniu się na równi z Dwunastoma, miało tu ostatecznie swoją względnie słuszną podstawę, gdyż brakowało mu faktycznie obcowania $z$ historycznym Jezusem. Stało się to dla Pawła pobudką do oparcia swego apostolatu na podstawach, które by uwalniały go od werdyktu drugorzędności. Takie postawienie sprawy miało zresztą podstawowe znaczenie dla koncepcji i roszczeń prachrześcijańskiego apostolatu $\mathrm{w}$ ogóle. Powiązanie apostolatu z życiem ziemskim Jezusa znalazło, po wtóre, swój wyraz we włączeniu się Pawła w prąd prachrześcijańskiej tradycji dotyczącej Jezusa. W ten właśnie sposób Paweł został wewnętrznie powiązany z dziejami Jezusa, które stały się jedyną podstawą i treścią także i Pawłowego przepowiadania. Ta podstawa jednoczyła Pawła i apostołów pragminy przy wszelkich przeciwieństwach, jakie między nimi się ujawniały ${ }^{128}$.

W osobnym ustępie, zamykającym artykuł na temat apostolos, poświęca Rengstorf szczególną uwagę zagadnieniu świadomości apostolskiej j Pawła. Świadomość ta, jak sądzi, została określona istotnie i w całości w spotkaniu Pawła z Jezusem pod Damaszkiem, które sprawiło, że apo. stolat Pawłowy był jedyny $\mathrm{w}$ swoim rodzaju. W apostolacie tym akcen-

127 H. Rengstorf, Die Zuwahl des Matthias, 47.

128 I (ThWNT) 438. 
tuje Rengstorf szczególnie świadomość prorockiego posłannictwa, z ktirym - jak sądzi - związane jest także szczególne stanowisko Pawła w kręgu pozostałych apostołów. Jest ono określone przez powołanie na posłańca na wzór żydowskiego šaliach, podobnie zresztą jak i powołanie innych apostołów. Szczególnie mocne zaakcentowanie przez Pawła tej strony i podstawy jego urzędu nastąpiło, zdaniem Rengstorfa, zwłaszcza na skutek tego, że wrogi mu obóz zaprzeczył, jakoby jego urząd był tego samego rodzaju i wartości co urząd pozostałych apostołów. Według wstępu listu do Galatów nastąpiło to w Galacji i przybrało taką formę, że autoryzację Pawła przypisano gminie w Antiochii, z której on wyszedł, lub Barnabie, który wprowadził go do pragminy ( $\mathrm{Dz} 9$, 27). Dlatego w Gal 1, 1 Paweł nazywa siebie apostołem nie z ludzkiego ustanowienia czy zlecenia, lecz z ustanowienia Jezusa Chrystusa i Boga Ojca, nastepnie poczynając od 1, 1 dowodzi niezależności swego apostolatu od ludzi, a od 2, 1 nn. równorzędności $\mathrm{z}$ innymi apostołami ${ }^{129}$.

Zwrócenie przez Rengstorfa uwagi na świadomość apostolską Pawła jest godne uznania. Nasuwają się tu jednak pewne zastrzeżenia. Jest rzeczą widoczną, że Rengstorf przesadnie wiąże tę świadomość z wydarzeniem pod Damaszkiem. Że wydarzenie to miało dla apostolatu Pawła decydujące znaczenie, nie ulega wątpliwości. Powstaje jednak pytanie, czy kształtowanie się jego świadomości apostolskiej zostało określone w zupełności pod Damaszkiem. Jeśli nawet wydarzenie pod Damaszkiem było widzeniem Zmartwychwstałego, to nie znaczy to jeszcze, że było ono tym samym, o którym pisze Paweł w 1 Kor 15, 5 i na innych miejscach w swych listach. Być może, że prócz zjawienia Chrystusa pod Damaszkiem nastąpiły w życiu Pawła jeszcze inne, lecz w takim razie należałoby przyjąć, że wszystkie one miały wpływ na kształtowanie się jego świadomości apostolskiej. Nadto także i objawienia, na które się Paweł w 2 Kor 12 powoluje, niekoniecznie musiały nastąpić podczas zjawień Chrystusa, a przecież i one musiały wywrzeć wpływ na tę świadomość.

\section{URZĄD KAZNODZIEJSKI A APOSTOLAT}

Zagadnieniem stosunku zachodzącego między urzędem kaznodziejskim a apostolatem zajął się Rengstorf w pracy pt. Apostolat und Predigtamt, opublikowanej w rok po ukazaniu się artykułu apostolos w ThWNT ${ }^{130}$. Nawiązując do osiągniętych tam wyników badawczych powtarza Rengstorf, że apostolat ze swej istoty jest zastępowaniem - Stellvertretung Jezusa. Nie jest on urzędem w dzisiejszym tego słowa znaczeniu, lecz czasowo i rzeczowo ograniczonym mandatem, polega zaś na przepowia-

129 Tamże, 438. 443.

130 H. Rengstorf, Apostolat und Predigtamt, 11-19. 
daniu słowa (Mt 10,7) oraz na działaniu w oparciu o otrzymaną plenipotencję (Mt 10,1), a więc na połączeniu słowa z czynem. Ponadto apostoł ma uczestnictwo w Duchu Bożym i w cierpieniach Chrystusa (Mt 10, 17 nn.) ${ }^{131}$. W tym widzi Rengstorf możliwość porównania między apostolatem a urzędem kaznodziejskim, bowiem apostolska plenipotencja przedstawiciela urzędu jest, zdaniem jego, zarówno dzisiaj jak i za czasów apostołów związana z poświęceniem swej woli i życia Jezusowi ${ }^{132}$.

Wskazanie przez Rengstorfa na podobieństwa i związki między urzędem apostolskim a urzędem kaznodziejskim jest bez wątpienia rzeczą słuszną. Między urzędami tymi zachodzą jednak również istotne różnice. Słabą stroną wymienionej rozprawy Rengstorfa jest to, że różnic tych nie ukazał. Zwrócił na to uwagę protestancki recenzent pracy Apostolat und Predigtamt, O. Michel ${ }^{133}$, według którego zasadniczym brakiem rozprawy Rengstorfa jest nieuwzględnienie aspektu eklezjologicznego. Michel wymienia następnie różnice, jakie zdaniem jego zachodzą między urzędem apostolskim a kaznodziejskim. Zalicza do nich przede wszystkim bezpośredniość powołania apostołów przez Jezusa i udzielenie im szczególnego pełnomocnictwa do budowania Kościoła, czego - jak sądzi - brak jest urzędowi kaznodziejskiemu. Z zastrzeżeniami Michela trzeba zgodzić się w zupełności. Dodać można, że różnic między wymienionymi urzędami jest znacznie więcej, co podkreślają zwłaszcza uczeni katoliccy ${ }^{134}$. Na szczególną uwagę zasługuje tutaj wytknięcie Rengstorfowi przez recenzenta protestanckiego nieuwzględnienia w ocenianej pracy aspektu eklezjologicznego. Brak ten daje się zresztą zauważyć w całej koncepcji apostolatu, jaką Rengstorf w kilku swych rozprawach wyłożył.

\section{UWAGI KONCOWE}

Mimo szeregu braków koncepcji Rengstorfa, na które w artykule niniejszym zwrócono uwagę, trzeba przyznać, że stanowi ona bardzo cenny wkład do badań nad zagadnieniem apostolatu nowotestamentalnego. O jej wartości świadczy choćby już tylko to, że po wielu dziesiątkach lat, jakie upłynęły od jej sformułowania, cieszy się ona nadal żywym zainteresowaniem uczonych, tak że nie można sobie dzisiaj wyobrazić badacza, który by w swych dociekaniach nad wymienionym zagadnieniem do niej nie nawiązywał. Nietrudno też zauważyć, że w wielu punktach ujawnia

131 Tamże.

132 Tamże, 26 nn.; 31.

133 O. Michel (rec.), Rengstorf, Apostolat und Predigtamt, ,Theologische Literaturzeitung”, Leipzig, 14 (1935) 255 n.

134 Zob. np. B. Bartmann, Lehrbuch der Dogmatik, II, 81932, 157; Y. Congar, Die apostolische Kirche, w: Mysterium Salutis. Grundriss heilsgeschichtlicher Doymatik, hrsg. von Feiner J. - Löhner M., IV/1, Einsiedeln 1972, 545-549. 
ona dal̉eko idącą zbieżność z podstawowymi tezami katolickiej nauki o apostolacie, przede wszystkim zaś co się tyczy tezy o powołaniu przez Jezusa Chrystusa apostołów i ukonstytuowaniu przezeń kolegium Dwunastu. Badania Rengstorfa pozwalają jednak w wielu momentach tezy te bliżej wyjaśnić, dokładniej sprecyzować i lepiej udokumentować, toteż winny zostać w szerokim zakresie wykorzystane przez teologię katolicką, tj. zarówno przez apologetykę jak i dogmatykę.

H. RENGSTORF'S KONZEPTION DES NEUTESTAMENTLICHEN APOSTOLATS UND IHRE AUSWIRKUNGEN IN DER PROTESTANTISCHEN LITERATUR VOR DEM II. VATIKANISCHEN KONZOL

\section{Z US A M M E N F A S S U N G}

Der Autor stellt die von H. Rengstorf - einem Vertreter des Luthertums in Schweden - ausgearbeitete Konzeption des neutestamentlichen Apostolats dar und weist gleichzeitig auf die Auswirkungen hin, die diese in der theologischen Literatur der Gegenwart hervorrief, wobei er auch den Versuch einer kritischen Einschätzung unternimmt.

In seinen der Problematik des neutestamentlichen Apostolats gewidmeten Forschungen, die Rengstorf bereits in noch vor dem II. Weltkrieg veröfentlichten Arbeiten unternahm, lassen sich zwei hauptsächliche, eng miteinander verbundene Themen hervorheben. Es sind das die Probleme der Genese und des Wesens des besagten Apostolats. Zur Erklärung der Genese des Apostolats unternimmt Rengstorf zuerst gründliche Forschungen über die Bedeutung des Verbs apostello und des Substantivs apostolos in der griechischen Literatur sowie über die entsprechenden Verb- und Substantivformen im hebräischen Text des Alten Testaments, danach Forschungen über die jüdische Institution schaliach, schliesslich über die Anwendung der erwähnten Bezeichnungen im Neuen Testament. Als Ergebnis dieser Forschungen legt der schwedische Gelehrte die Bedeutung des Verbs apostello im Neuen Testament als mit (in Gott begründeter) Vollmacht aussenden zum Dienste am Reiche Gottes, das Substantiv apostolos als bevollmächtigter Gesandter fest.

Das Problem der Bezeichnung der Art der Beziehung zwischen der Institution schaliach und dem christlichen Apostolat ist diskutabel. Zahlreiche Autoren wie D. Müller, J. Roloff, E. Lohse, G. Klein suggerieren den Gedanken, Rengstorf habe diese Beziehung als genetische Abhängigkeit verstanden. Der Autor dieses Artikels ist gegen eine solche Ansicht. Nach einer kritischen Analyse der entsprechenden Argumentierung der erwähnten Forscher kommt dieser zu dem Schlusse, der eigentliche Gedanke Rengstorf's ginge dahin, dass beide Institutionen bestimmte gemeinsame Eigenschaften aufweisen, vor allem diese, dass sowie schaliach als auch Apostel bevollmächtigte Vertreter sind.

Hinsichtlich der Genese des Apostolats sieht Rengstorf hier 2 Etappen. Es sind das die Ernennung der Apostel durch den iridischen Jesu sowie die Erneuerung dieses Aktes durch den Auferstandenen Jesus. Rengstorf's Auffassung nach riefen diese Ereignisse nicht nur das neutestamentliche Apostolat ins Leben, vielmehr setzten sie gleichzeitig dessen Natur fest. 
Rengstorf vertritt ganz entschieden die historische Ernennung der zwölf Apostel durch irdischen Jesu und führt eine Reihe von Argumenten an. die seiner Ansicht nach diese Tatsache beweisen. Der Autor dieses Artikles weist hierbei darauf hin, dass man aus der entsprechenden Argumentierung Rengstorf's zwei verschiedene, obwohl eng miteinander verbundene Probleme ausscheiden kann, u. zw. das Problem des historischen Akts der Konstituierung des Kollegiums der Zwölf durch den irdischen Jesus sowie das Problem des Aktes der Emennung der Apostel durch ihn.

Der Standpunkt der nach Rengstorf sicht mit diesem Problem befassenden protestantischen Theologen war vierschieden. Die zahlreiste Gruppe (W. Kümmel, H. Campenhausen, A. Fridrichsen, I. Munck, E. Lohse) sprach sich für die histcrische Ernennung der Zwölf bezw. einer kleinen Gruppe von Jüngern durch den irdischen Jesus aus, erkannte ihr jedoch eine bestimmte Form apostolischen Wirkens - in diesem konkreten Falle missionärischen Charakters - erst nach Ostern zu, wobei sie Paul als den eigentlichen Schöpfer der Bezeichnung „Apostel" und überhaupt der christlichen Auffassung des Begrifis „Apostel" anerkannte. Eine zweite, nicht allzu zahlreiche Gruppe der radikalsten Forscher aus der Schule von R. Bultmann (G. Klein, W. Schmithals, P. Vielhauer) verwarf sowohl das Historische des Aktes der Konstituierung des Kreises der Zwölf durch den irdischen Jesus und sprach ihnen zudem jegliche apostolischen Eigenschaften ab. Eine dritte Gruppe, die ebenfalls nicht zahlreich ist, sprach sich sowohl für das Historische als auch für das Apostolat der Zwölf aus.

Eine eingehende Kritik der Argúmente Rengstorf's, die für das Historische des Kollegiums der Zwölf zur Zeit des Erdenlebens Jesu und für deren apostolischen Charakter sprechen, führte G. Klein durch. Der Autor dieses Artikels polemisiert mit dem erwähnten Autor und kommt zu dem Schlusse, dass Rengstorf's Feststellungen begrüdet sind. Dabei beruft er sich zusätzlich auf die kritische Einschätzung der Ansichten von Klein und Schmithals, die wir dem schwedischen protestantischen Theologen B. Gerhardsson verdanken.

Mit der Problematik des Geschichtlichen des Kollegiums der Zwölf und ihres apostolischen Charakters ist das Problem der Erwählung des Matthias zum Apostel verbunden. Mit diesem Problem befasste sich Rengstorf in einer schon nach dem II. Weltkrieg veröffentlichten Arbeit. In dem vorliegenden Artikel verden die von Rengstorf in jener Arbeit dargelegten Ansichten angeführt. Bei dieser Gelegenheit werden ebenfalls die Ansichten von E. Haenchen besprochen, des Autors des bekannten Kommentars zu der Apostelgeschichte, da dessen Standpunkt der Grund war, der Rengstorf veranlasste, mit ihm zu polemisieren. Auf die Frage hin, was Lukas bewegte, zu eingangs der Apostelgeschichte die Überlieferung von der Erwählung des Matthias anzuführen, geben beide erwähnte Autoren verschiedene Antwort, wobei der eine von ihnen deutlich die Antwort des anderen negiert und verwirft. Der Autor des Artikels nimmt teilweise eine kritische Stellung diesen Antworten gegenüber ein, modifiziert sie etwas und schlägt eine eigene Lösung vor.

Auf den wesentlichen Verlauf der Ausführungen, die jene Ansichten Rengstorf's anführen und beurteilen, welche dieser in seinen Artikeln aus der Vorkriegszeit darlegte, zurückkommend, nimmt der Autor des Artikels ebenfalls eine kritische Stellung ein hinsichtlich der Aussage des erwähnten Gelehrten, als er die Texte Mt 10, 40 f.; Mk 9, 41; Lk 10, 16 in dem Sinn interpretiert, dass es sich Jesu lediglich um eine Verbindung des Apostolats mit der Idee des Dienstes und der Unterwerfung gehandelt hat und dass er sich nicht bemüht hat ein 
rechtmässig gestaltetes Gemeindeamt zu schaffen. Die rechtlichen Forderungen sollten dagegen charakteristisch sein für Paul's Auffassung des Apostolats. Nach Ansicht des Autors dieses Artikels würde eine derartige Darstellung des Problems zu dem Schlusse führen, dass Paul's Konzeption des Apostolats nicht mit Jesu Vorhaben übereinstimmte - eine derartige Schlussfolgerung würde ihrerseits wiederum die Authentizität der Begegnung Paul's mit dem Auferstandenen und die Echtheit seiner Offenbarungen in Zweifel stellen.

Mit der Bestimmung des Wesens des Apostolats befasst sich Rengstorf bei der Darlegung seiner Ansichten zum Thema der zweiten Etappe des Entstehens des Apostolats. Diese Etappe ist - seiner Ansicht nach - die Erneuerung des Auftrags an die Jünger in ihrer endgültigen Bestimmung zu Aposteln. Aus dem Inhalt der Ausführungen Rengstorf's geht hervor, dass die Erteilung des Auftrags durch den Auferstandenen als letzter Faktor, der das Entstehen des Apostolats entscheidet, anzusehen ist. Zu den zweitrangigen Eigenschaften des Apostolats zählt er dagegen die Sendung der Apostel zu missionärischem Wirken.

Der Autor des Artikels sieht den Standpunkt Rengstorf's hinsichtlich der Einmaligkeit des Apostolats als unbegründet an. Der schwedische: Gelehrte vertriut nämlich die Ansicht, dass das erneuerte und von dem Aufgestandenen endgültig konstituierte Apostolat einen bleibenden Charakter trägt, da dieser seine Vertreter für den ganzen Zeitraum zwischen Ostern und seiner Wiederkunft bestellt hat. Er bestellte sie jedoch nur einmal, woraus hervorgeht, dass das Apostolat auf die erste Generation der Christen beschränkt blieb und nicht zu einem kirchlichen Amt wurde. Der Autor ist der Ansicht, die Ausführungen Rengstorf's machen einen kontradiktorischen Eindruck.

Rengstorf widmet in seinen Ausführungen dem Apostolat Paul's ebenfalls ziemlich viel Platz. Der Ansicht des Autors nach sollte man die Beobachtungen Rengstorf's uber die Verbindung des Apostolats Paul's mit seinem persönlichen Anteil am Leben Jesu als treffend ansehen. Bemerkenswert ist auch der Hinweis Rengstorf's auf das apostolische Selbstbewusstsein Paul's, mit dem einzigen Vorbehalt, dass der schwedische Gelehrte dieses Selbstbewusstsein zu stark mit dem Geschehnis in Damaskus verband, ohne die Rolle anderer Visionen und Offerbarungen des Apostels in Betracht zu ziehen.

Der letzte der in diesem Artikel besprochenen Punkte der Doktrin Rengstorf's vom Apostolat ist das Problem des Verhältnisses zwischen dem Predigtamt und dem Apostolat. Rengstorf befasste sich damit in seiner Arbeit u.d.T. Apostolat und Predigtamt, der erstmals im Jahre 1934 veröffentlicht und im Jahre 1954 erneut herausgegeben wurde. In Anlehnung an die in seinen früheren Veröffentlichungen dargelegten Forschungsergebnisse vertritt er den Standpunkt, das Apostolat sei wesentlich eine Stellvertretung. Es sei kein Amt im Sinne der gegenwärtigen Bedeutung des Wortes, sondern ein zeitlich und gegenständlich beschränkter, auf erhaltener Vollmacht beruhender Auftrag. Ausserdem habe der Apostel seinen Anteil am Geiste Gottes und an den Leiden Christi. Rengstorf sieht darin die Möglichkeit eines Vergleichs zwischen dem Apostolat und dem Predigtamt, da seiner Ansicht nach die apostolische Vollmacht eines amtlichen Vertreters sowohl gegenwärtig als auch zur Zeit der Apostel der Widmung des eigenen Willens und Lebens für Jesus gleichkommt.

Der Autor des Artikels erachtet den Hinweis Rengstorf's auf die Ähnlichkeit und den Zusammenhang zwischen dem Apostolat und dem Predigtamt als richtig und ist der Meinung, die schwache Seite des erwähnten Traktats sei die Ausserachtlassung der zwischen diesen Ämtern bestehenden wesentlichen Unterschiede. 
Auch der protestantische Rezensent der Arbeit Apostolat und Predigtamt O. Michel wies ebenfalls darauf hin, seiner Ansicht nach ist die Ausserachtlassung des eklesiologischen Faktors eine wesentliche Lücke in Rengstorf's Arbeit.

Sämtliche von Rengstorf's dargelegten Ansichten über das neutestamentliche Apostolat zusammenfassend kommt der Autor zu dem Schlusse, dass trotz einer Reihe von Lücken die Konzeption des Gelehrten ein wertvoller Beitrag zu den Forchungen an dem erwähnten Problem bedeutet. Weiter stellt der Autor fest, dass diese Konzeption in zahlreichen Punkten eine weitgehende Úbereinstimmung mit den Grundthesen der katholischen Lehre vom Apostolat aufweist. Er fügt jedoch hinzu, dass die Konzeption eine genauere Erklärung dieser Thesen, eine Präzisierung, eine bessere Dokumentierung zulasse, wie sie auch - seiner Meinung nach - weitgehend durch die katholische Theologie ausgenützt werden sollte u.zw. sowohl durch die Apologetik als auch die Dogmatik. 